\title{
Exergy and economic comparison between kW-scale hybrid and stand-alone solid oxide fuel cell systems
}

\author{
Michael M. Whiston ${ }^{\mathrm{a}, *}$, William O. Collinge ${ }^{\mathrm{b}}$, Melissa M. Bilec $^{\mathrm{b}}$, \\ Laura A. Schaefer ${ }^{c}$ \\ ${ }^{a}$ Department of Engineering and Public Policy, Carnegie Mellon University, 5000 Forbes \\ Avenue, Pittsburgh, Pennsylvania 15213, USA \\ ${ }^{b}$ Department of Civil and Environmental Engineering, University of Pittsburgh, \\ 3700 O'Hara Street, Pittsburgh, Pennsylvania 15261, USA \\ ${ }^{c}$ Department of Mechanical Engineering, Rice University, \\ 6100 Main Street, Houston, Texas, 77005, USA
}

\begin{abstract}
Although hybrid solid oxide fuel cell (SOFC) microturbine systems generate power more efficiently than stand-alone SOFC systems, hybrid systems remain in the demonstration phase. The present study compares a hybrid system's exergetic and economic performance with that of a stand-alone system. Both systems meet a university building's kW-scale power demand. The hybrid system operates at $66 \%$ exergetic efficiency, and the stand-alone system operates at $59 \%$ exergetic efficiency. Increasing the fuel cell's operating voltage increases the systems' exergetic efficiencies, and varying the fuel cell's temperature, pressure, and fuel utilization influences the systems' exergetic performances, though to a lesser extent. The present study calculates the systems' life cycle costs. We find that the systems' life cycle costs depend significantly on the systems' operation. During baseline operation,
\end{abstract}

\footnotetext{
*Corresponding author

Email address: mwhiston@andrew.cmu.edu (Michael M. Whiston)
} 
the hybrid system costs less than the stand-alone system. After optimizing the systems during cogeneration operation, the hybrid system costs slightly more than the stand-alone system. Overall, our findings support hybrid systems continued research and development; it is recommended that future work simulate hybrid and stand-alone systems under a range of thermal-toelectric ratios to reflect different building types and operation.

Keywords: solid oxide fuel cell; microturbine; hybrid; economic; energy; exergy

\section{NOMENCLATURE}

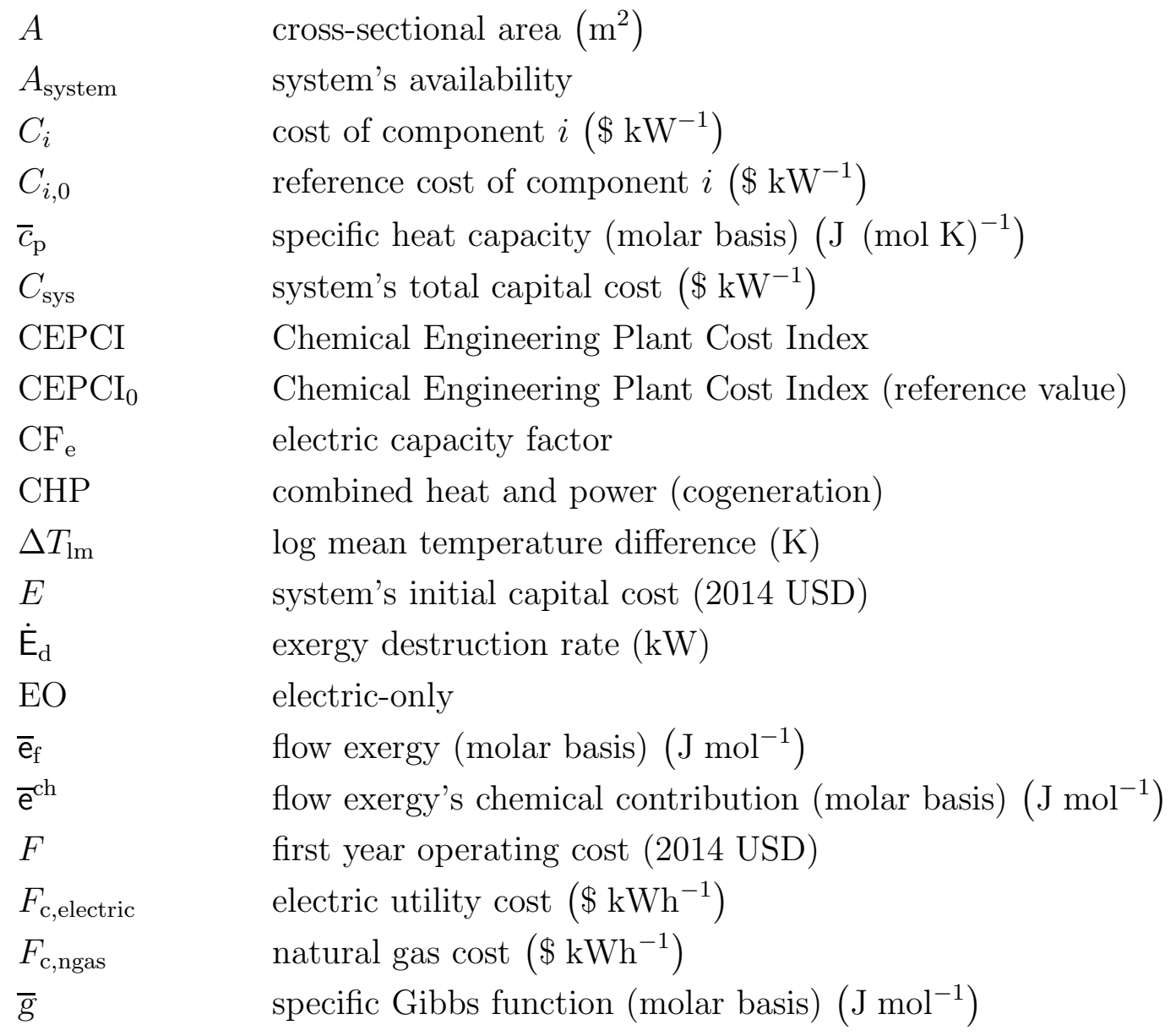


higher heating value $\left(\mathrm{J} \mathrm{mol}^{-1}\right)$ specific enthalpy (mass basis) $\left(\mathrm{J} \mathrm{kg}^{-1}\right)$ specific enthalpy (molar basis) $\left(\mathrm{J} \mathrm{mol}^{-1}\right)$ life cycle cost life cycle savings lower heating value $\left(\mathrm{J} \mathrm{mol}^{-1}\right)$ mass flow rate $\left(\mathrm{kg} \mathrm{s}^{-1}\right)$ capacity scaling exponent molar flow rate $\left(\mathrm{mol} \mathrm{s}^{-1}\right)$ ratio of life cycle operating cost to first year operating cost ratio of life cycle capital cost to initial capital cost pressure $(\mathrm{Pa})$ reference pressure $(\mathrm{Pa})$ annual average thermal energy demand $\left(\mathrm{kW}_{\mathrm{th}}\right)$ thermal energy recovery $(\mathrm{kW})$ universal gas constant $\left(8.314 \mathrm{~J}(\mathrm{~mol} \mathrm{~K})^{-1}\right)$ capacity of component $i$ reference capacity of component $i$ entropy (molar basis) $\left(\mathrm{J}(\mathrm{mol} \mathrm{K})^{-1}\right)$ temperature $(\mathrm{K})$ reference temperature $(\mathrm{K})$ boundary temperature $(\mathrm{K})$ average PEN temperature $(\mathrm{K})$ overall heat transfer coefficient $\left(\mathrm{kW}\left(\mathrm{m}^{2} \mathrm{~K}\right)^{-1}\right)$ fuel utilization operating fuel cell voltage $(\mathrm{V})$ velocity $\left(\mathrm{m} \mathrm{s}^{-1}\right)$ annual average power demand $(\mathrm{kW})$ net power $(\mathrm{kW})$ fuel cell stack's DC power $(\mathrm{kW})$ mole fraction of species $i$ in the environment 


\section{Greek symbols}

$\begin{array}{ll}\varepsilon_{\text {sys }} & \text { system's exergetic efficiency } \\ \eta_{\text {SOFC }, \mathrm{e}} & \text { fuel cell's electric efficiency } \\ \eta_{\text {sys }, \mathrm{CHP}} & \text { system's cogeneration efficiency } \\ \eta_{\text {sys,e }} & \text { system's electric efficiency } \\ \lambda_{\text {air }} & \text { air ratio (-) } \\ \text { Subscripts } & \\ 0 & \text { environmental property (dead state) } \\ \text { blower } & \text { air blower } \\ \text { comp } & \text { compressor } \\ \text { m } & \text { mixed flow } \\ \text { p } & \text { primary flow } \\ \text { PEN } & \text { positive electrode-electrolyte-negative electrode } \\ \text { s } & \text { secondary flow } \\ \text { sys } & \text { system } \\ \text { turb } & \text { turbine }\end{array}$

\section{Introduction}

Integrating a solid oxide fuel cell (SOFC) stack with a microturbine (MT) enables an SOFC system to generate power relatively efficiently. Hybrid SOFC-MT systems have the potential to achieve electric efficiencies approaching $70 \%$ (LHV) [1-6]. On their own, microturbines generate power at approximately 30\% (LHV) electric efficiency [7, 8], and stand-alone SOFC systems operate between 52\%-65\% (LHV) electric efficiency [9]. Hybrid systems integrate a fuel cell stack with a microturbine, enabling these systems to generate greater power per unit input energy than either system alone. In addition, unlike most commercial SOFC systems, which operate the SOFC stack near 
atmospheric pressure, hybrid systems may pressurize the SOFC stack, placing the stack immediately after the air compressor. Pressurization enhances the fuel cell's performance by increasing the fuel cell's reversible potential. Hybrid systems also have the potential to reduce $\mathrm{CO}_{2}$ emissions relative to more conventional systems due to their relatively high electric efficiency. Other emissions, such as $\mathrm{NO}_{\mathrm{x}}$ and $\mathrm{SO}_{\mathrm{x}}$, may fall below those of more conventional systems. SOFCs emit negligible $\mathrm{SO}_{\mathrm{x}}$, in particular, as the natural gas is desulfurized prior to entering the fuel cell stack [10].

While hybrid systems operate at high electric and overall efficiencies, these systems remain in the demonstration phase. The National Fuel Cell Research Center at the University of California, Irvine tested a $220 \mathrm{~kW}$ hybrid system in the early 2000s [11-13], and FuelCell Energy, Inc. developed a hybrid system consisting of a molten carbonate fuel cell stack and gas turbine [14]. Neither system, however, is commercially developed. Stand-alone systems, on the other hand, are available. Bloom Energy [9], Atrex Energy [15], and Protonex [16] have developed stand-alone systems for a variety of $\mathrm{kW}$ and sub-kW-scale applications, including communications and sensors, data centers, retail stores, and remote power applications. In order for hybrid systems to compete in the distributed generation market, they must demonstrate favorable performance on the $\mathrm{kW}$-scale.

The present study compares a hybrid system's exergetic and economic performance with that of a stand-alone system. Using exergy, we identify sources of inefficiency in both systems. Moran, et al. define exergy as follows:

Exergy is the maximum theoretical work obtainable from an overall system consisting of a system and the environment as the sys- 
tem comes into equilibrium with the environment (passes to the dead state). [17, p. 362, emphasis in the original]

We also investigate the influence of the fuel cell's operating parameters on the systems' exergetic efficiencies, finding that increasing the fuel cell's operating voltage significantly improves the systems' exergetic efficiencies. In the second part of this study, we calculate each system's life cycle cost from the owner's perspective. The life cycle cost formula incorporates the systems' equipment, operation, and supplemental energy costs. The present study parametrically varies the systems' operating parameters in order to identify local minima in the systems' life cycle costs.

Throughout this study, the term "hybrid" refers to the integration of the SOFC stack with a microturbine. The fuel cell stack operates under pressure, situated between the air compressor and turbine. Alternatively, the fuel cell stack may be placed after the turbine [18-21]. Such a configuration, however, typically reduces the system's efficiency $[18,20]$. SOFCs may be integrated with other devices, such as a polymer electrolyte membrane fuel cell stack [21, 22], absorption chiller [21, 23], photovoltaic array [24], and wind turbine $[21,24]$. We have chosen to integrate the fuel cell stack with a microturbine, as microturbines are established combined heat and power (CHP) technologies whose operating temperature and pressure coincide with those of SOFCs. The working fluid passes from the fuel cell stack to the turbine, obviating the need for a heat exchanger. Zhang, et al. [21] refer to this configuration as a "direct thermal coupling" scheme. 
Previous exergy analyses have focused largely on either hybrid or standalone systems, typically on the MW-scale. Few (if any) studies, however, have compared hybrid and stand-alone systems in the low to mid-kW range $(50 \mathrm{~kW}-250 \mathrm{~kW})$. Calise, et al. [25] performed one of the earliest exergy studies on a 1.5 MW hybrid system. The authors found that the largest exergy destruction occurred in the SOFC stack, followed by the afterburner. Calise, et al. [26] performed an exergy analysis of a 1.5 MW hybrid system during part-load operation, finding that the system's part-load performance depended largely on the system's control strategy. Gandiglio, et al. [27] performed an exergy and thermoeconomic comparison between $280 \mathrm{MW}$ hybrid and stand-alone systems. Similar to Calise, et al. [25], these authors found that the hybrid system's SOFC stack and afterburner destroyed the most exergy, whereas in the stand-alone system, the air preheater and afterburner destroyed the most exergy. Chan, et al. [28] found that the afterburner and vaporizer destroyed the most exergy in a methane-fueled, MW-scale, standalone system. Douvartzides, et al. [29] also performed an exergy analysis of a methane-fueled, stand-alone system, finding that decreasing the reforming factor increased the system's exergetic efficiency.

Previous economic studies have considered small (residential-scale, 1$2 \mathrm{~kW}$ ) and large (MW) systems. To the authors' knowledge, however, no previous economic studies have compared hybrid and stand-alone systems in the 50-250 kW range. Gandiglio, et al. [27] performed a thermoeconomic comparison between multi-MW pressurized and atmospheric power plants. The authors found that the pressurized and atmospheric systems exhibited similar levelized costs of electricity, whereas the hybrid system ex- 
hibited a lower thermoeconomic levelized cost of electricity. Santin, et al. [30] performed a techno-economic analysis of a $500 \mathrm{~kW}$ hybrid system with different fuels, finding that methanol-fueled systems yielded higher internal rates of return on investment than kerosene-fueled systems. Fontell, et al. found a $250 \mathrm{~kW}$ stand-alone system to be economically competitive with a conventional gas engine [31]. Numerous other studies have considered large (baseload) SOFC power plants [32-44]. On the residential-scale, Braun [4547] performed a techno-economic analysis of several different SOFC system configurations with heat recovery. Braun found that the methane-fueled system with anode gas recycle and $100 \%$ internal reforming saved the most money among the feasible options. Hawkes and Leach [48-50] and Hawkes, et al. [51-54] also considered residential-scale, CHP SOFC systems.

Section 2 describes the atmospheric and pressurized systems, as well as the previously developed fuel cell stack model. Section 2 also describes the systems' baseline operating parameters and building loads. Section 3 presents the systems' exergetic performances during baseline operation and the systems' exergy accountings. The sensitivity analysis varies the fuel cell's operating parameters and microturbine pressure ratio. Section 4 describes the cost model. The cost model incorporates the systems' first costs, operating costs, and supplemental energy costs. The parametric analysis varies the fuel cell's and turbomachinery's operating parameters. Section 5 concludes the present study. 


\section{System descriptions}

\subsection{Stand-alone system}

The present study integrates a previously developed fuel cell stack model [55-58] with two overall systems derived from previous studies [1-6, 21, 30, 40, 41, 44, 46, 59-66]. The system models were developed in the iterative equation solver software, Engineering Equation Solver (EES) [67]. Figure 1 presents the stand-alone system. This configuration is based on the methanefueled, $100 \%$ internal reforming design with anode gas recycle presented by Braun [46]. Braun found this configuration to save more money than other configurations without requiring the complex controllability and equipment costs associated with cathode gas recycle. The chosen system also reflects stand-alone systems developed by U.S. companies Atrex Energy and FuelCell Energy, Inc. Atrex Energy [59] develops an internal reforming tubular SOFC. FuelCell Energy, Inc. [60] develops molten carbonate fuel cell systems that employ $100 \%$ internal reforming. Similar to the systems modeled in the present study, both of these commercial systems operate at sufficiently high temperatures to cogenerate steam or hot water.

Table 1 presents the systems' baseline operating parameters. In the standalone system, air enters the air blower at state 1, where it is compressed to overcome the system's air-side pressure drop. The air is then pre-heated to a temperature suitable for SOFC operation between states 2 and 3. The temperature of air entering the air channel is iteratively determined by the temperature rise across the air channel, which is specified to be $150^{\circ} \mathrm{C}$ in both systems based on the maximum allowable thermal strain in a fuel cell $[6$, $62,68]$. The average positive electrode-electrolyte-negative electrode (PEN) 


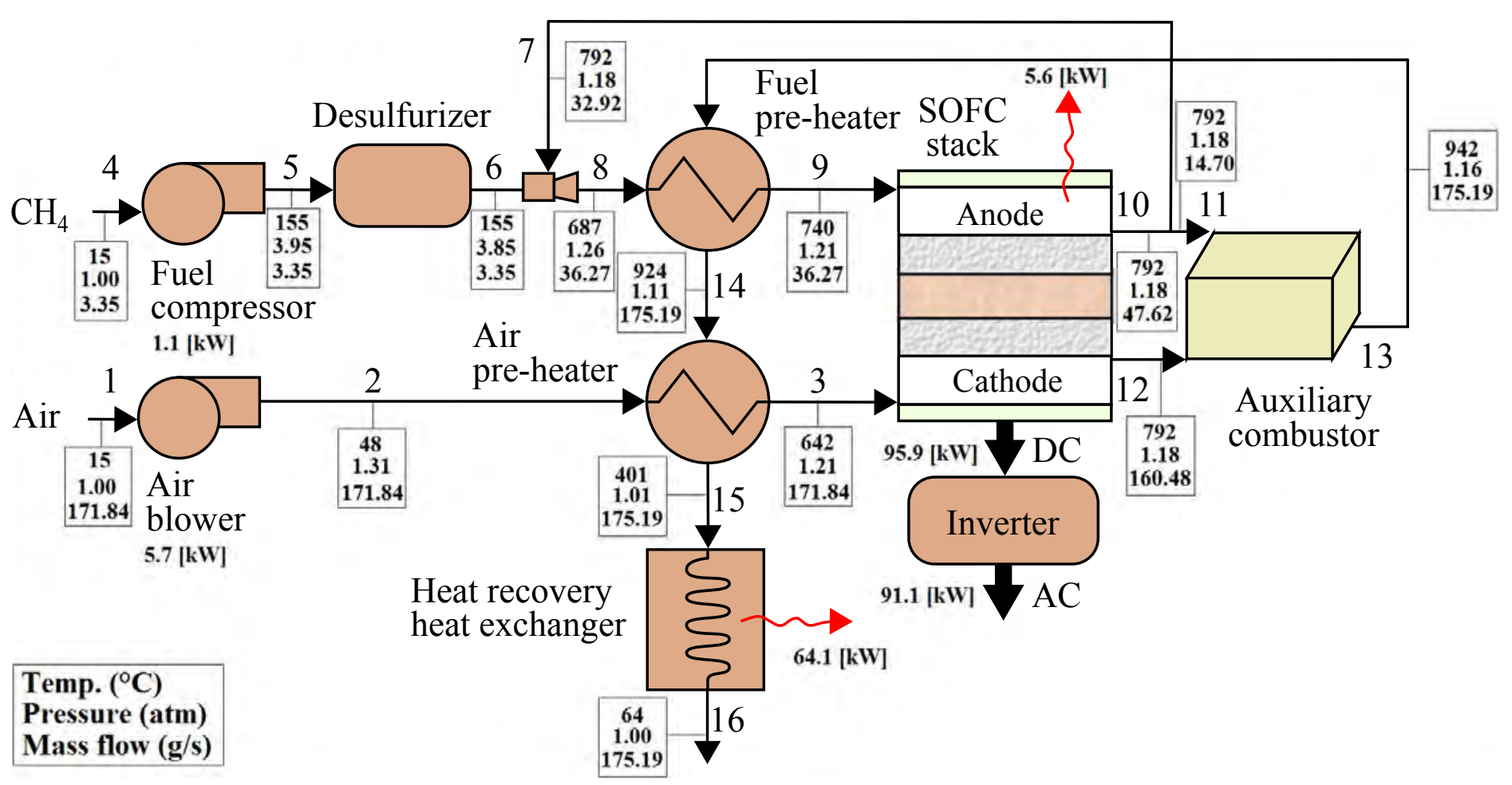

Figure 1 The stand-alone system's process flow diagram (adapted from Refs. [46, 59, 60]). Thermodynamic properties are provided during baseline operation (Table 1).

temperature, specified to be $750^{\circ} \mathrm{C}$, iteratively determines the inlet air flow rate in both systems. Intermediate-temperature SOFCs typically operate between $550^{\circ} \mathrm{C}$ and $800^{\circ} \mathrm{C}[69]$. Methane enters the fuel compressor at state 4, where it is compressed to overcome the system's fuel-side pressure drop. The fuel is desulfurized (states 5 and 6) and pre-heated (states 8 and 9). In both systems, the temperature of the fuel entering the stack is specified to be $10^{\circ} \mathrm{C}$ less than the average PEN temperature. The fuel cell stack generates DC power, which is inverted to AC power at $95 \%$ efficiency. Part of the anode exhaust circulates back to the fuel pre-heater at state 7. Anode gas recycle maintains a steam-to-carbon (S/C) ratio of 2.5 at the fuel cell stack's inlet, 
Table 1 Baseline operating parameters.

\begin{tabular}{lll}
\hline \multicolumn{1}{c}{ Parameter } & \multicolumn{2}{c}{ Value } \\
& \multicolumn{1}{c}{ Stand-alone } & \multicolumn{1}{c}{ Hybrid } \\
\hline Net power & $84.2 \mathrm{~kW}$ & $84.2 \mathrm{~kW}$ \\
Thermal energy demand & $170.8 \mathrm{~kW}$ th & $170.8 \mathrm{~kW}$ th \\
Fuel cell voltage & $0.7 \mathrm{~V}$ & $0.7 \mathrm{~V}$ \\
System fuel utilization & 0.85 & 0.85 \\
Pressure ratio & - & 4 \\
Turbine inlet temperature & - & $1,125^{\circ} \mathrm{C}$ \\
Average PEN temperature & $750^{\circ} \mathrm{C}$ & $750^{\circ} \mathrm{C}$ \\
Fuel channel inlet temperature & $740^{\circ} \mathrm{C}$ & $740^{\circ} \mathrm{C}$ \\
Air channel temperature rise & $150^{\circ} \mathrm{C}$ & $150^{\circ} \mathrm{C}$ \\
S/C ratio & 2.5 & 2.5 \\
Inverter efficiency & $95 \%$ & $95 \%$ \\
Air blower efficiency & $70 \%$ & - \\
Air compressor efficiency & - & $80 \%$ \\
Fuel compressor efficiency & $70 \%$ & $70 \%$ \\
Turbine efficiency & - & $80 \%$ \\
Stack thermal energy loss $(\%$ inlet $\mathrm{HHV})$ & $3 \%$ & $3 \%$ \\
\hline
\end{tabular}

thereby reducing the risk of solid carbon formation inside the fuel cell stack [70]. Unreacted fuel exits the fuel cell stack at state 10 and reacts in the auxiliary combustor. The exhaust pre-heats the incoming fuel (states 13 and 14) and air (states 14 and 15). The heat recovery heat exchanger recovers thermal energy for cogeneration between states 15 and 16. In both systems, the exhaust exits the system $25^{\circ} \mathrm{C}$ above the dew point temperature.

\subsection{Hybrid system}

Figure 2 presents the hybrid system. The present model resembles previous configurations, which have considered fuel and air bypasses and external reforming [1-6, 30, 40, 41, 44, 61-66]. The configuration in Fig. 2 most closely 


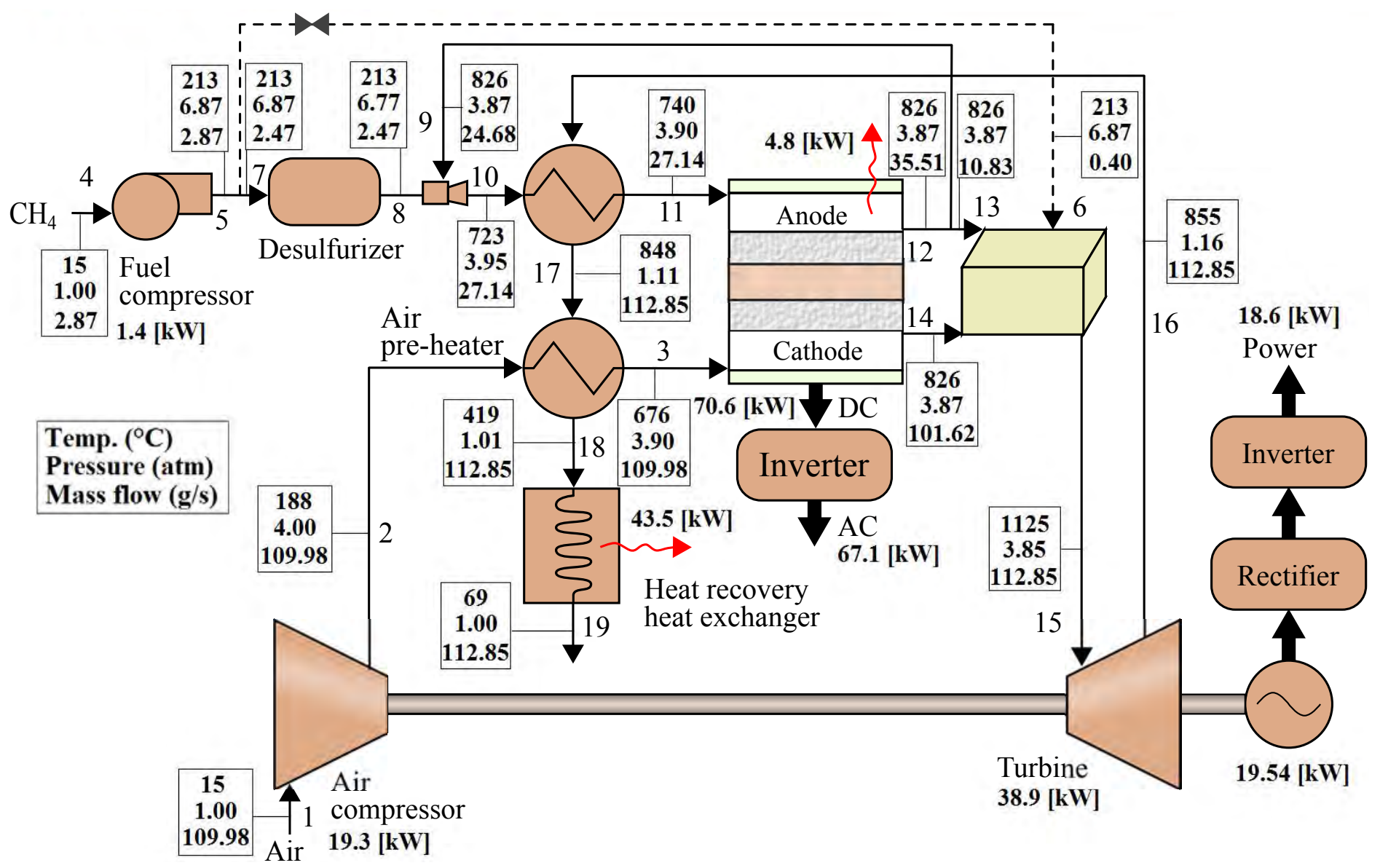

Figure 2 The hybrid system's process flow diagram (adapted from Refs. [1-6, 21, 30, 40, 41, 44, 61-66]). Thermodynamic properties are provided during baseline operation (Table 1).

resembles Chan, et al.'s configuration [1,3]. These authors bypassed the fuel directly to the combustor in order to increase the turbine inlet temperature. The $220 \mathrm{~kW}$ experimental system developed by Siemens Westinghouse and tested at the National Fuel Cell Research Center [11-13] similarly employed a fuel bypass to control the mass flow through the system.

In the hybrid system, air enters the air compressor at state 1 , where it 
is compressed to a pressure ratio of four $[1,3]$. The air is then pre-heated between states 2 and 3. Air enters the hybrid system's fuel cell stack at a temperature higher than it enters the fuel cell stack in the stand-alone system. Air flows at a lower mass flow rate in the hybrid system, giving rise to a higher stack exit air temperature and correspondingly higher inlet air temperature to maintain a fixed cathode temperature rise. Methane enters the fuel compressor at state 4 , where it is compressed to a pressure ratio slightly greater than four due to the fuel-side component pressure drops. The fuel is desulfurized between states 7 and 8 and pre-heated between states 10 and 11. Similar to the stand-alone system, part of the anode exhaust circulates back to the fuel cell stack's inlet at state 9. Unlike the standalone system, however, part of the hybrid system's fuel may pass directly to the auxiliary combustor at state 6 in order to maintain the turbine inlet temperature at $1,125^{\circ} \mathrm{C}$. The system's exhaust pre-heats the incoming fuel (states 16 and 17) and air (states 17 and 18). Finally, the heat recovery heat exchanger recovers thermal energy for cogeneration between states 18 and 19.

\subsection{Fuel cell stack}

The hybrid and stand-alone systems incorporate a previously developed 1-D, co-flow, numerical SOFC stack model [55-58]. The fuel cell model is a $10 \mathrm{~cm} \times 10 \mathrm{~cm}, 18$ channel, planar design whose material and geometric properties are presented in the International Energy Agency's Annex II reports [71, 72 (citing [73])] and repeated in Braun [45]. The fuel cell model discretizes the gas channels, PEN structure, fuel-side and air-side interconnects along the flow direction, accounting for axial changes in current 
density, temperature, composition, and pressure. The activation (ButlerVolmer equation), concentration (Fick's law of diffusion), and ohmic (electrical resistivity) polarizations reduce the fuel cell's operating voltage below the Nernst potential. The water-gas shift reaction occurs at equilibrium, and the methane steam reforming reaction proceeds according to Achenbach and Riensche's kinetic expression [74]. The fuel cell's energy balance accounts for convection in the gas channels, and conduction and cross-channel radiation in the solid components. Heat transfer also occurs between adjacent fuel cells' fuel and air channels. The momentum balance accounts for momentum change and wall shear stress, giving rise to the gas channel pressure drops. Identical equations and operating parameters govern each fuel cell in the stack. The charges, species mass, energy, and momentum balances may be simulated dynamically, although the present study considers only steady-state behavior.

The present study modifies the fuel cell stack model since its presentation in our previous study in two respects [55]. Previously, the fuel cell stack model accounted for radiation between the stack and stainless steel container, treating radiation as a boundary condition. We found, however, that this boundary condition gave rise to an unreasonably small air temperature rise in the air channel. Thus, we chose to remove the radiation boundary condition and instead assume that the fuel cell stack's container loses $3 \%$ of the system's inlet fuel energy (HHV) to the environment [33, 39, 47]. Second, we modified the fuel cell's design to reflect intermediate-temperature operation. Our previous study [55] considered an electrolyte-supported design. The present study considers an anode-supported design. Anode-supported fuel 
cells operate at approximately $750^{\circ} \mathrm{C}$, thereby permitting the use of metallic interconnects. Metallic interconnects reduce the fuel cell stack's cost. Thijssen [75] provides typical dimensions for anode-supported fuel cells, and the present work adopts these values. The anode is $325 \mu \mathrm{m}$ thick, the electrolyte is $8 \mu \mathrm{m}$ thick, and the cathode is $50 \mu \mathrm{m}$ thick. The interconnect's thermal conductivity equals $25 \mathrm{~W}(\mathrm{~m} \mathrm{~K})^{-1}[69]$.

\subsection{Balance of plant (BOP) components}

The BOP components comprise the fuel and air compressors, fuel and air pre-heaters, desulfurizer, ejector, auxiliary combustor, heat recovery heat exchanger, and inverter. Each BOP model calculates the exit mass flow rate, temperature, and pressure based on the corresponding inlet quantities and 0-D mass and energy balances. The energy balance applied to the air blower, air compressor, and fuel compressor yields the exit temperature [17]:

$$
T_{\text {exit }}=T_{\text {inlet }}+\frac{T_{\text {inlet }}}{\eta_{\text {blower(comp) }}}\left(\left(\frac{p_{\text {exit }}}{p_{\text {inlet }}}\right)^{\frac{\bar{R}}{\bar{c}_{\mathrm{p}}}}-1\right)
$$

where $T_{\text {exit }}$ is the exit temperature, $T_{\text {inlet }}$ is the inlet temperature, $\eta_{\text {blower(comp) }}$ is the blower's (or compressor's) isentropic efficiency, $p_{\text {exit }}$ is the exit pressure, $p_{\text {inlet }}$ is the inlet pressure, $\bar{R}$ is the universal gas constant, and $\bar{c}_{\mathrm{p}}$ is the ideal gas mixture's molar specific heat capacity. The turbine's exit temperature is calculated similarly [17]:

$$
T_{\text {exit }}=T_{\text {inlet }}+\eta_{\text {turb }} T_{\text {inlet }}\left(\left(\frac{p_{\text {exit }}}{p_{\text {inlet }}}\right)^{\frac{\bar{R}}{\overline{\bar{p}}_{\mathrm{p}}}}-1\right)
$$


where $\eta_{\text {turb }}$ is the turbine's isentropic efficiency. The power consumed or generated by each rotating device equals the enthalpy change across the device.

The fuel and air pre-heaters operate in counter-flow. The heat exchangers calculate the $U A$ product, which is the product of a heat exchanger's overall heat transfer coefficient $(U)$ and heat exchange area $(A)$. The $U A$ product indicates a heat exchanger's size, which is used in the cost model to estimate the heat exchanger's capital cost (Section 4). The log mean temperature difference relates the $U A$ product to the heat exchanger's heat rate as follows:

$$
q=U A \Delta T_{\mathrm{lm}}
$$

where $\Delta T_{\operatorname{lm}}$ is the $\log$ mean temperature difference [76].

The ejector overcomes the anode recycle loop's pressure drop by entraining the recycled gas. The anode recycle loop's pressure drop comprises the fuel pre-heater and fuel-side stack pressure drops. The mixed flow exits the ejector at a pressure greater than the secondary flow but less than the primary flow. Bird, et al. [77] present the ejector model, which Liso [78] and Braun, et al. [47] implemented in SOFC system models. The primary fluid's diameter equals $3.31 \mathrm{~mm}$, and the mixed fluid's diameter equals $20.4 \mathrm{~mm}$ $[79,80]$. Mass, momentum, and energy balances yield the mixed flow's mass flow rate, primary flow's pressure, and mixed flow's temperature:

$$
\begin{gathered}
\dot{m}_{\mathrm{m}}=\dot{m}_{\mathrm{p}}+\dot{m}_{\mathrm{s}} \\
v_{\mathrm{m}} \dot{m}_{\mathrm{m}}+p_{\mathrm{m}} A_{\mathrm{m}}=v_{\mathrm{p}} \dot{m}_{\mathrm{p}}+p_{\mathrm{p}} A_{\mathrm{p}}+v_{\mathrm{s}} \dot{m}_{\mathrm{s}}+p_{\mathrm{s}} A_{\mathrm{s}} \\
\dot{m}_{\mathrm{m}}\left(h_{\mathrm{m}}+\frac{1}{2} v_{\mathrm{m}^{2}}\right)=\dot{m}_{\mathrm{p}}\left(h_{\mathrm{p}}+\frac{1}{2} v_{\mathrm{p}^{2}}\right)+\dot{m}_{\mathrm{s}}\left(h_{\mathrm{s}}+\frac{1}{2} v_{\mathrm{s}^{2}}\right)
\end{gathered}
$$


where $\dot{m}$ denotes the mass flow rate, $v$ denotes the velocity, and $A$ denotes the cross-sectional area. The subscripts $m, p$, and $s$ denote the mixed, primary, and secondary flows, respectively.

Lastly, pressure drops occur across each system component. Braun [47] estimated the pressure drops across fuel cell system components based on several previous studies [81-83], and the present study adopts Braun's estimates. The pressure drops across the fuel and air-preheaters equal 50 mbar and 100 mbar, respectively, and the heat recovery heat exchanger's pressure drop equals 15 mbar. The desulfurizer's pressure drop equals 100 mbar, and the auxiliary combustor's pressure drop equals 20 mbar. The fuel-side and air-side fuel cell stack pressure drops both equal $30 \mathrm{mbar}$. These values remain constant, regardless of the system's operating point. For more detail, the reader is referred to Ref. [57].

\subsection{Building loads}

The hybrid and stand-alone systems meet the annual average power demand of a recent addition to the University of Pittsburgh's engineering building, the Mascaro Center for Sustainable Innovation (MCSI). We collected data during the winter semester, winter break, summer semester, and summer break. Based on data collected during these time periods, MCSI consumes $84.2 \mathrm{~kW}$ on average annually. The electric loads include plug loads, lights, fans for the air-handling units, and miscellaneous equipment. MCSI consumes $170.8 \mathrm{~kW}_{\text {th }}$ of hot water on average annually. The hot water demand includes the hot water used by the radiators and air-handling units. The hot water demand excludes cooling energy, which is produced externally in the central chilled water system. Both systems produce exhaust streams 
at approximately $440^{\circ} \mathrm{C}$ prior to heat recovery, which is suitable for heating water.

\section{Energetic and exegetic analyses}

\subsection{Exergy balance}

A system reaches equilibrium with its environment when it assumes the environment's temperature, pressure, and composition. In order to model the systems' exergetic performances, the present work adopts the equations and methodology presented in Moran, et al. [17] and Klein and Nellis [84]. The steady-state exergy balance applied to each system component is given by the following equation:

$$
0=\sum_{i=1}^{\# \text { transfers }}\left(1-\frac{T_{0}}{T_{i}}\right) \dot{Q}_{i}-\dot{W}+\sum_{i=1}^{\# \text { inlets }} \dot{n}_{\mathrm{in}, i} \overline{\mathrm{e}}_{\mathrm{f}, \mathrm{in}, i}-\sum_{i=1}^{\# \text { exits }} \dot{n}_{\mathrm{out}, i} \overline{\mathrm{e}}_{\mathrm{f}, \mathrm{out}, i}-\dot{\mathrm{E}}_{\mathrm{d}}
$$

where $T_{0}$ is the environment's temperature, $T_{i}$ is the boundary temperature at which heat transfer $\dot{Q}_{i}$ occurs, $\dot{W}$ is the power generation, $\dot{n}_{\mathrm{in}, i}$ is the molar flow rate entering inlet $i, \overline{\mathrm{e}}_{\mathrm{f}, \mathrm{in}, i}$ is the molar flow exergy entering inlet $i, \dot{n}_{\mathrm{out}, e}$ is the molar flow rate leaving exit $i, \overline{\mathrm{e}}_{\mathrm{f}, \mathrm{out}, e}$ is the molar flow exergy leaving exit $i$, and $\dot{\mathrm{E}}_{\mathrm{d}}$ is the exergy destruction. The specific flow exergy is given by the following formula:

$$
\overline{\mathrm{e}}_{\mathrm{f}}=\bar{h}-\bar{h}_{0}-T_{0}\left(\bar{s}-\bar{s}_{0}\right)+\overline{\mathrm{e}}^{\mathrm{ch}}
$$

where $\bar{h}$ is the fluid's molar enthalpy evaluated at the inlet or exit conditions, $\bar{h}_{0}$ is the fluid's molar enthalpy evaluated at the environment's conditions, 
$T_{0}$ is the environment's temperature, $\bar{s}$ is the molar entropy evaluated at the inlet or exit conditions, $\bar{s}_{0}$ is the fluid's molar entropy evaluated at the environment's conditions, and $\bar{e}^{\mathrm{ch}}$ is the chemical exergy. The present work assumes $T_{0}=25^{\circ} \mathrm{C}$ and $p_{0}=1$ atm.

\subsection{Performance metrics}

The system's exergetic efficiency is defined as the ratio of the desired products' exergy to the inlet exergy:

$$
\varepsilon_{\mathrm{sys}}=\frac{\dot{W}_{\text {net }}+\left(1-\frac{T_{0}}{T_{b}}\right) \dot{Q}_{\text {recovery }}}{\left(\dot{n}_{\text {fuel }} \cdot \overline{\mathrm{e}}_{\mathrm{f}}\right)_{\text {system,inlet }}}
$$

where $\dot{W}_{\text {net }}$ is the net power, $T_{0}$ is the environment's temperature $(298.15 \mathrm{~K})$, $T_{\mathrm{b}}$ is the system's boundary temperature, $\dot{Q}_{\text {recovery }}$ is the thermal energy recovered, $\dot{n}_{\text {fuel }}$ is the fuel molar flow rate, and $\overline{\mathrm{e}}_{\mathrm{f}}$ is the flow exergy [84]. The numerator in Eqn. (9) accounts for exergy associated with both power generation and heat recovery. The factor $\left(1-T_{0} / T_{b}\right)$ may be interpreted as the Carnot efficiency, which represents the maximum amount of work that could be obtained from $\dot{Q}_{\text {recovery }}$. The system's overall (cogeneration) efficiency is defined as the ratio of the system's output energy to the inlet fuel energy:

$$
\eta_{\text {sys }, \mathrm{CHP}}=\frac{\dot{W}_{\text {net }}+\dot{Q}_{\text {recovery }}}{\left(\dot{n}_{\text {fuel }} \cdot \mathrm{HHV}_{\text {fuel }}\right)_{\text {system,inlet }}}
$$

where $H V_{\text {fuel }}$ is the fuel's higher heating value [47]. The system's electric efficiency is defined as the ratio of the net power to the fuel's energy [47]:

$$
\eta_{\text {sys }, \mathrm{e}}=\frac{\dot{W}_{\text {net }}}{\left(\dot{n}_{\text {fuel }} \cdot H H V_{\text {fuel }}\right)_{\text {system,inlet }}}
$$


and the fuel cell's stack's electric efficiency is defined similarly:

$$
\eta_{\text {stack,e }}=\frac{\dot{W}_{\text {SOFC,DC }}}{\left(\dot{n}_{\text {fuel }} \cdot H H V_{\text {fuel }}\right)_{\text {system,inlet }}}
$$

where $\dot{W}_{\text {SOFC,DC }}$ is the DC power generated by the fuel cell [45].

The air ratio and fuel utilization indicate the system's reactant consumption. The air ratio is defined as the oxygen molar flow rate divided by twice the methane molar flow rate [47]:

$$
\lambda_{\text {air }}=\frac{\dot{n}_{\mathrm{O}_{2}, \text { system,inlet }}}{2 \dot{n}_{\mathrm{CH}_{4}, \text { system,inlet }}}
$$

The system's fuel utilization represents the portion of the system's fuel that is oxidized inside the fuel cell stack. The fuel utilization is defined as follows:

$$
U_{\mathrm{f}, \mathrm{sys}}=\frac{\dot{n}_{\mathrm{H}_{2}, \mathrm{consumed}}}{4 \dot{n}_{\mathrm{CH}_{4}, \mathrm{sys}}}
$$

where $U_{\mathrm{f}, \mathrm{sys}}$ is the system's fuel utilization, $\dot{n}_{\mathrm{H}_{2} \text {,consumed }}$ is the molar flow rate of $\mathrm{H}_{2}$ consumed by the fuel cell stack, and $\dot{n}_{\mathrm{CH}_{4} \text {,sys }}$ is the molar flow rate of methane entering the system [47]. The denominator in Eqn. (14) represents the amount of $\mathrm{H}_{2}$ yielded by the reforming and water-gas shift reactions, assuming that all of the fuel species are converted to $\mathrm{H}_{2}, \mathrm{CO}_{2}$, and $\mathrm{H}_{2} \mathrm{O}$.

\subsection{Results}

\subsubsection{Baseline operation}

Table 2 presents the stand-alone and hybrid systems' energetic and exergetic results during baseline operation. The hybrid system's exergetic efficiency exceeds that of the stand-alone system by about six percentage points. 
Table 2 The stand-alone and hybrid systems' results during baseline operation.

\begin{tabular}{lll}
\hline & Stand-alone & Hybrid \\
\hline Exergetic efficiency & $59.2 \%$ & $65.5 \%$ \\
Cogeneration efficiency & $79.7 \%$ & $80.2 \%$ \\
System's electric efficiency & $45.3 \%$ & $52.9 \%$ \\
Stack's electric efficiency & $51.5 \%$ & $44.3 \%$ \\
Thermal energy recovered & $64.2 \mathrm{~kW}_{\text {th }}$ & $43.5 \mathrm{~kW}_{\text {th }}$ \\
Thermal energy loss & $5.6 \mathrm{~kW}_{\text {th }}$ & $4.8 \mathrm{~kW}_{\text {th }}$ \\
Air ratio & 3.0 & 2.6 \\
\hline
\end{tabular}

The stand-alone system recovers approximately $50 \%$ more thermal energy than the hybrid system recovers, but the hybrid system operates at a higher electric efficiency than the stand-alone system. Table 3 presents the standalone system's exergy accounting. Exergy accounting is the evaluation of each component's exergy destruction, exergy loss, power, and cogeneration, presented in a form that allows for easy comparison between components [17]. The left column in Table 3 represents the exergy output associated with power generation and thermal energy recovery, and the right column represents the exergy that is destroyed or lost. Based on the results in Table 3, the air pre-heater destroys the most exergy. Air experiences a large temperature rise across the air pre-heater (nearly $600^{\circ} \mathrm{C}$, as shown in Fig. 1). Air also forms the system's bulk flow, as indicated by the air ratio presented in Table $2\left(\lambda_{\text {air }}=3.0\right)$. Thus, significant heat transfer and exergy destruction occur in the air pre-heater. The fuel cell stack and auxiliary combustor also destroy and lose significant exergy. The chemical and electrochemical reactions inside these components give rise to irreversibilities [25]. The remaining components, including the heat recovery heat exchanger, inverter, 
Table 3 The stand-alone system's exergy accounting. All values are expressed as a percentage of the system's inlet exergy.

\begin{tabular}{lcc}
\hline & $\begin{array}{l}\text { Power or } \\
\text { cogeneration }(\%)\end{array}$ & $\begin{array}{l}\text { Exergy destroyed } \\
\text { or lost }(\%)\end{array}$ \\
\hline Fuel cell stack & 52.4 & 9.9 \\
Fuel compressor & -0.7 & 0.1 \\
Air blower & -3.3 & 0.9 \\
Desulfurizer & - & 0.0 \\
Ejector & - & 1.6 \\
Fuel pre-heater & - & 0.6 \\
Air pre-heater & - & 13.7 \\
Heat recovery & 10.8 & 3.6 \\
Auxiliary combustor & - & 5.9 \\
Inverter & - & 2.8 \\
Exhaust & - & 1.7 \\
Sum & & 40.8 \\
\hline
\end{tabular}

ejector, air blower, and fuel compressor, destroy smaller amounts of exergy, and a small fraction of the inlet exergy exits with the system exhaust.

Table 4 presents the hybrid system's exergy accounting. The fuel cell stack and auxiliary combustor destroy and lose significant amounts of exergy. The remaining components destroy smaller amounts of exergy. Unlike the stand-alone system, the hybrid system's air pre-heater destroys about $5 \%$ of the system's inlet exergy. In the hybrid system, the air experiences a lower temperature rise across the air pre-heater compared to the stand-alone system due to the compressor's pre-heating. The hybrid system's air flow rate is also less than the stand-alone system's air flow rate. Consequentially, the hybrid system's air pre-heater transfers less heat, and thus, destroys less exergy than the stand-alone system's air pre-heater. The hybrid system's 
Table 4 The hybrid system's exergy accounting. All values are expressed as a percentage of the system's inlet exergy.

\begin{tabular}{lcc}
\hline & $\begin{array}{l}\text { Power or } \\
\text { cogeneration }(\%)\end{array}$ & $\begin{array}{l}\text { Exergy destroyed } \\
\text { or lost }(\%)\end{array}$ \\
\hline Fuel cell stack & 45.1 & 8.4 \\
Fuel compressor & -1.0 & 0.2 \\
Air compressor & -12.3 & 1.7 \\
Turbine & 24.8 & 1.8 \\
Desulfurizer & - & 0.0 \\
Ejector & - & 1.3 \\
Air pre-heater & - & 4.9 \\
Fuel pre-heater & - & 0.3 \\
Heat recovery & 8.9 & 3.0 \\
Power conditioning (stack) & - & 2.4 \\
Power conditioning (turbomachinery) & - & 0.6 \\
Auxiliary combustor & - & 8.1 \\
Exhaust & - & 1.9 \\
& & \\
Sum & 65.5 & 34.6 \\
\hline
\end{tabular}

exergetic performance furthermore depends on the turbomachinery's operation. The air compressor consumes $12 \%$ of the system's inlet exergy, and the turbine converts nearly $25 \%$ of the system's inlet exergy to mechanical power.

\subsubsection{Sensitivity analysis}

Figure 3 presents the stand-alone system's energetic and exergetic results vs. the fuel cell's operating voltage (Fig. 3a), fuel utilization (Fig. 3b), and average PEN temperature (Fig. 3c). During each sensitivity analysis, all operating parameters otherwise assume their baseline values (Table 1). As shown in Fig. 3a, increasing the fuel cell's operating voltage from slightly over $0.5 \mathrm{~V}$ to $0.8 \mathrm{~V}$ increases the system's exergetic efficiency from $45 \%$ to $67 \%$. Higher voltages correspond to higher fuel cell electric efficiencies, re- 
sulting in higher exergetic efficiencies. Figure $3 \mathrm{a}$ also indicates that the heat recovery declines at higher voltages, which is likely due to the declining waste heat production inside the fuel cell stack at higher voltages. The waste heat production equals the enthalpy change of reaction minus the power generated by the fuel cell stack. As shown in Fig. 3b, increasing the system's fuel utilization from 0.77 to 0.90 decreases the system's exergetic efficiency by about two percentage points, despite the system's higher electric efficiency at higher fuel utilizations. Increasing the system's fuel utilization decreases the amount of fuel combusted in the auxiliary combustor, resulting in lower exhaust temperatures. Lower exhaust temperatures, in turn, reduce both the quantity and quality (temperature) of the recovered thermal energy, resulting in lower exergetic efficiencies. Increasing the average PEN temperature from $650^{\circ} \mathrm{C}$ to $850^{\circ} \mathrm{C}$ increases the system's exergetic efficiency by about two percentage points (Fig. 3c). Increasing the PEN temperature increases the fuel cell stack's power density, thereby decreasing the required fuel cell stack area. 


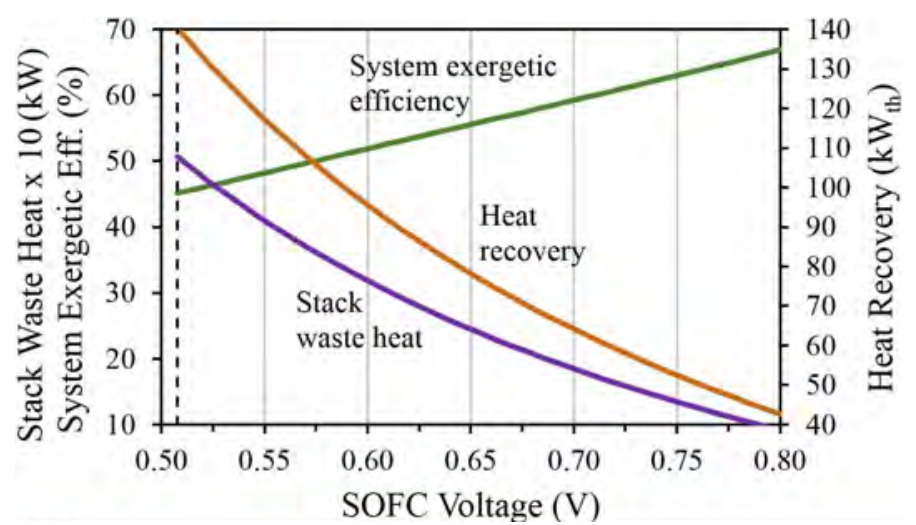

(a)

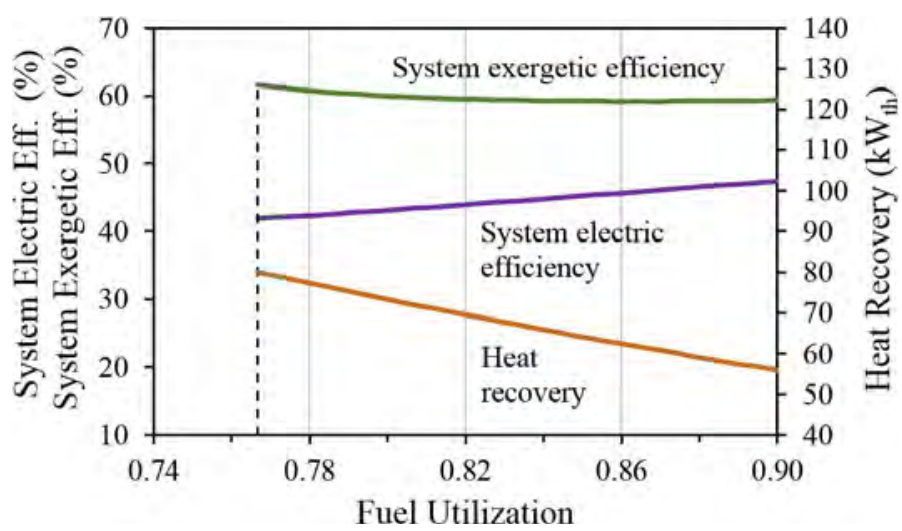

(b)

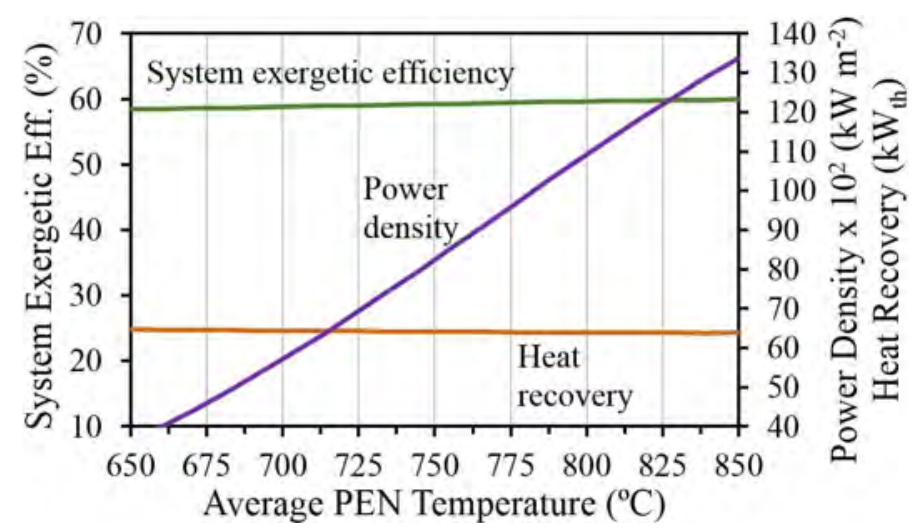

(c)

Figure 3 Sensitivity of the stand-alone system's energetic and exergetic results to changes in the fuel cell's operating parameters: (a) Varying the SOFC's voltage, (b) Varying the system's fuel utilization, (c) Varying the average PEN temperature. The dashed lines indicate the minimum value of the independent variable at which a solution was found. 
Figure 4 presents the hybrid system's energetic and exergetic results as a function of the fuel cell's operating voltage (Fig. 4a), fuel utilization (Fig. 4b), average PEN temperature (Fig. 4c), and the microturbine's pressure ratio (Fig. 4d). Increasing the fuel cell's operating voltage increases the system's exergetic efficiency by 12 percentage points. In Fig. 4b, increasing the system's fuel utilization decreases the system's exergetic efficiency. Increasing the system's fuel utilization reduces the amount of fuel combusted in the auxiliary combustion, resulting in lower turbine inlet temperatures. In order to maintain the turbine inlet temperature at $1,125^{\circ} \mathrm{C}$, the system requires additional methane (stream 6 in Fig. 2). The additional methane reduces the system's electric efficiency. As shown in Fig. 4c, increasing the average PEN temperature increases the system's exergetic efficiency. The heat recovery, on the other hand, declines at higher temperatures. The reduction in required stack cooling with increasing PEN temperature likely explains the reduction in air ratio and heat recovery. Finally, Fig. 4d indicates that increasing the pressure ratio reduces the amount of thermal energy recovered, but not sufficiently to reduce the system's exergetic efficiency. The rise in net turbine power, which equals the power generated by the turbine minus the power consumed by the air compressor, explains the exergetic efficiency's rise with increasing pressure ratio. 


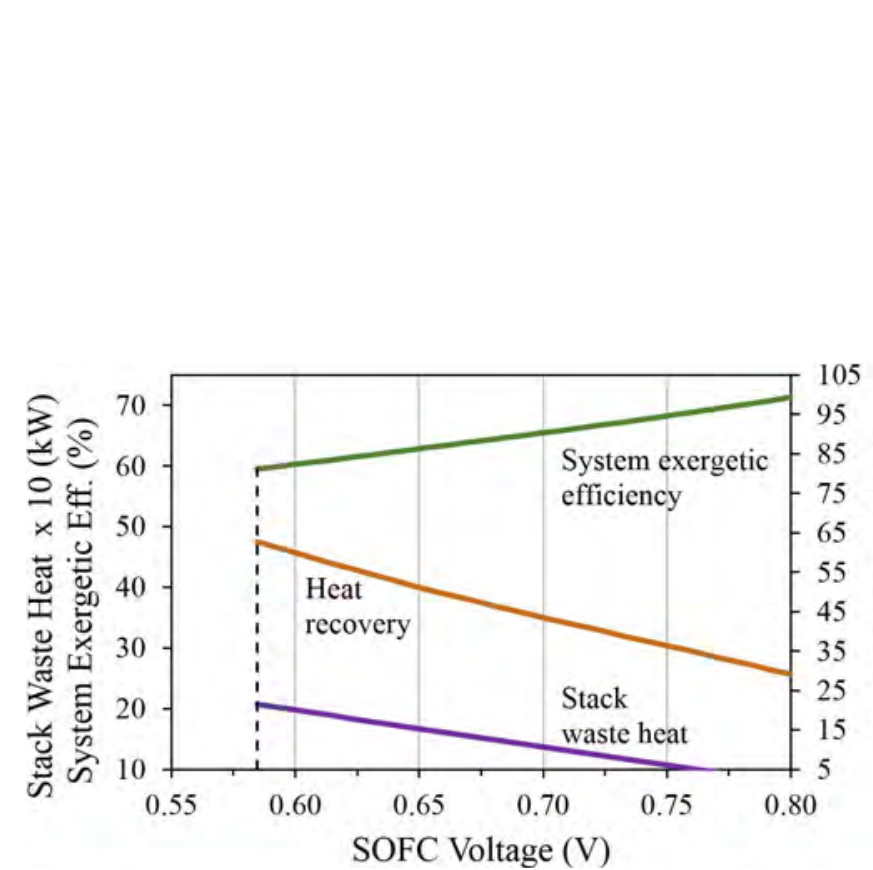

(a)

25

26

27

28

29

30

31

32

33

34

35

36

37

38

39

40

41

42

43

44

45

46

47

48

49

50

51

52

53

54

55

56

57

58

59

60

61

62

63

64

65

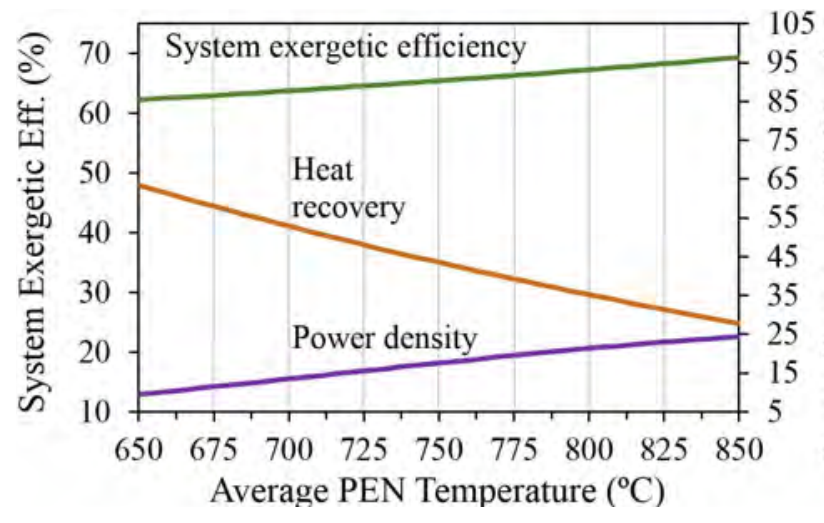

(c) variable at which a solution was found.

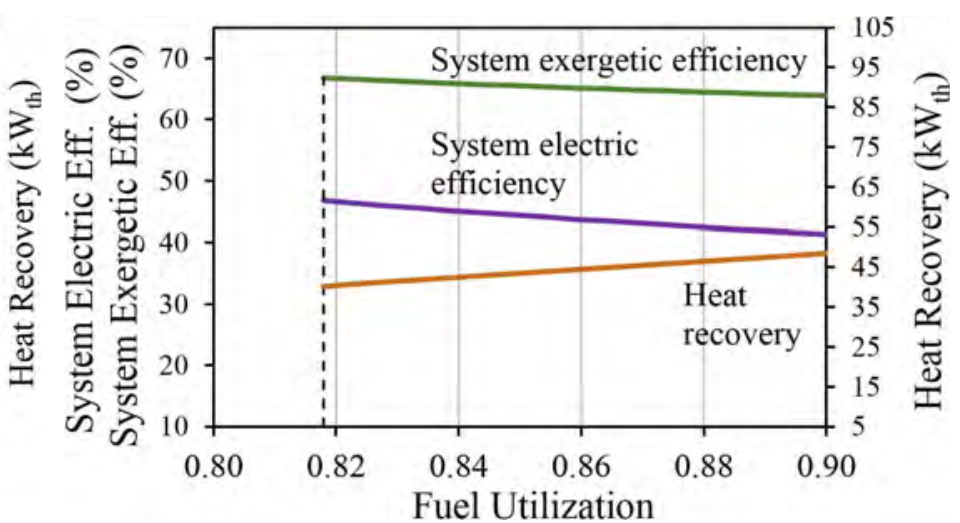

(b)

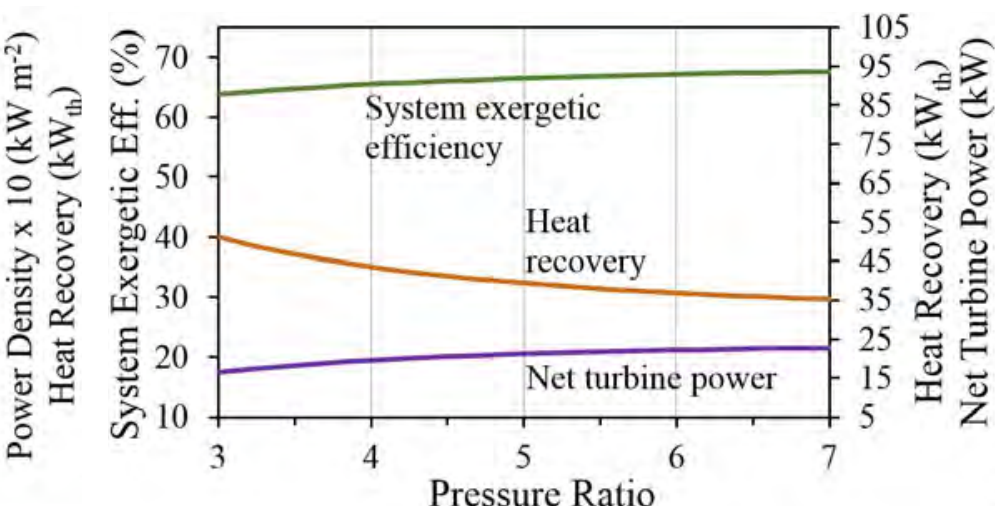

(d)

Figure 4 Sensitivity of the hybrid system's energetic and exergetic results to changes in the fuel cell's operating parameters: (a) Varying the SOFC's voltage, (b) Varying the system's fuel utilization, (c) Varying the average PEN temperature, (d) Varying the pressure ratio. The dashed lines indicate the minimum value of the independent 


\section{Economic analysis}

While energy and exergy provide useful metrics for evaluating a system's thermodynamic performance, investment decisions depend on a system's life cycle cost. A system's life cycle cost includes fuel costs, capital costs, maintenance costs, and salvage value. A system's life cycle cost also includes utility costs if utilities provide supplemental thermal energy and electricity to a building. The present study adopts Duffie and Beckman's $P_{1}-P_{2}$ method [85] to calculate the hybrid and stand-alone systems' life cycle costs. Subsection 4.1 describes the cost model. Subsection 4.2.1 presents the systems' baseline costs, and Subsections 4.2.2 and 4.2.3 vary the systems' operating parameters.

\subsection{Cost model}

Duffie and Beckman's $P_{1}-P_{2}$ method yields a system's life cycle cost:

$$
\mathrm{LCC}=P_{1} F+P_{2} E
$$

where $P_{1}$ is the ratio of the system's life cycle operating cost to the first year's operating cost, $F$ is the first year operating cost in dollars, $P_{2}$ is the ratio of the system's life cycle capital cost to the initial capital cost, and $E$ is the initial capital cost in dollars [85] . The constant $P_{1}$ is a present worth factor that accounts for inflation. The constant $P_{2}$ accounts for numerous other factors, including a down payment, loan interest, income tax, property tax, insurance, maintenance, depreciation, and the system's salvage value. The $P_{1}-P_{2}$ method, as applied to grid-connected fuel cell systems, also accounts for utility costs. In the present study, the power grid provides supplemental 
power when the fuel cell stack is unable to meet demand, and an auxiliary boiler provides supplemental thermal energy. The $P_{1}-P_{2}$ method applied to grid-connected fuel cell systems takes the following form [46]:

$$
\begin{aligned}
\mathrm{LCC}_{\mathrm{system}}= & P_{1, \mathrm{utility}, \text { ngas }}\left(F_{\mathrm{system}, \text { ngas }}+F_{\text {utility,ngas,supp }}\right) \\
& +P_{1, \mathrm{utility}, \text { electric }} F_{\text {utility,electric,supp }}+P_{2, \text { system }} E_{\text {system }}
\end{aligned}
$$

where the first term on the right-hand side of Eqn. (16) represents the cost of natural gas consumed by the system and auxiliary boiler, the second term represents the cost of supplemental grid power, and the third term represents the system's capital cost.

The present work adopts Braun's methodology [46] to calculate the first year operating costs. The system's first year natural gas cost is given by:

$$
F_{\text {system,ngas }}=\frac{\dot{W}_{\text {net }} \times 8,760 \mathrm{~h} \times \mathrm{CF}_{\mathrm{e}} A_{\text {system }} F_{\mathrm{C}, \text { ngas }}}{\eta_{\text {sys }, \mathrm{e}}}
$$

where $\mathrm{CF}_{\mathrm{e}}$ is the electric capacity factor, $A_{\text {system }}$ is the system's availability, and $F_{\mathrm{C} \text {,ngas }}$ is the natural gas price. In Eqn. (17), notice that the net power is multiplied by 8,760 hours to yield the power generated per year. The cost of natural gas consumed by the auxiliary boiler depends on the supplemental thermal energy required by the building, which is calculated according to the following formula:

$$
F_{\text {utility,ngas,supp }}=\frac{\left(\dot{Q}_{\text {demand,average }}-\dot{Q}_{\text {recovery }} \mathrm{CF}_{\mathrm{e}} A_{\text {system }}\right) \times 8,760 \mathrm{~h} \times F_{\mathrm{C}, \text { ngas }}}{\eta_{\text {boiler }}}
$$

where $\dot{Q}_{\text {demand,average }}$ is the average thermal energy demand, and $\eta_{\text {boiler }}$ is the auxiliary boiler's thermal efficiency. Similarly, the cost associated with 
drawing supplemental power is given by:

$$
F_{\text {utility,electric,supp }}=\dot{W}_{\text {net }} \times 8,760 \mathrm{~h} \times F_{\mathrm{C}, \text { electric }} \times\left(1-\mathrm{CF}_{\mathrm{e}} A_{\text {system }}\right)
$$

where $F_{\mathrm{C} \text {,electric }}$ is the electric utility price. The power grid meets demand when the fuel cell stack is unavailable or operates at less than capacity.

The present study also calculates the systems' life cycle savings. A system's life cycle savings reflects a system's economic performance relative to that of a conventional system. The conventional system consists of the power grid and an auxiliary boiler. The present work adopts Braun's methodology [46] to calculate the life cycle savings. The life cycle savings is given by:

$$
\mathrm{LCS}=\mathrm{LCC}_{\text {utility }}-\mathrm{LCC}_{\text {system }}
$$

where LCC $_{\text {utility }}$ is the utility's life cycle cost. The utility's life cycle cost is given by:

$$
\mathrm{LCC}_{\text {utility }}=P_{1, \text { utility,ngas }} F_{\text {utility,ngas,only }}+P_{1, \text { utility,electric }} F_{\text {utility,electric,only }}
$$

In Eqn. (21), $F_{\text {utility,ngas,only }}$ is the auxiliary boiler's operating cost during utility-only operation, and $F_{\text {utility,electric,only }}$ is the electric utility's cost during utility-only operation. The auxiliary boiler's operating cost is given by:

$$
F_{\text {utility,ngas,only }}=\frac{\dot{Q}_{\text {demand,average }} \times 8,760 \mathrm{~h} \times F_{\mathrm{C}, \text { ngas }}}{\eta_{\text {boiler }}}
$$


and the electric utility's cost is given by:

$$
F_{\text {utility,electric,only }}=\dot{W}_{\text {demand,average }} \times 8,760 \mathrm{~h} \times F_{\mathrm{C}, \text { electric }}
$$

where $\dot{W}_{\text {demand,average }}$ is the average annual power demand.

The present study adopts a bottom-up approach to estimating the system's capital cost, approximating each component cost based on previous estimates in the literature and scaling these estimates to the desired size. The component cost is given by:

$$
C_{i}=C_{i, 0}\left(\frac{S_{i}}{S_{i, 0}}\right)^{n} \frac{\mathrm{CEPCI}}{\mathrm{CEPCI}_{0}}
$$

where $C_{i}$ is the cost of component $i$ in $\$ \mathrm{~kW}^{-1}, C_{i, 0}$ is the reference cost of component $i$ in $\$ \mathrm{~kW}^{-1}, S_{i}$ is the capacity of component $i, S_{i, 0}$ is the reference capacity of component $i, n$ is the capacity scaling exponent, CEPCI is the Chemical Engineering Plant Cost Index, and $\mathrm{CEPCI}_{0}$ is the reference Chemical Engineering Plant Cost Index [86]. ${ }^{1}$ Table 5 presents each component's reference capacity, reference cost, and scaling exponent. Numerous studies provide these parameters [37, 45, 46, 87-91]. The National Energy Technology Laboratory [37] estimates the fuel cell cost to be $\$ 540 \mathrm{~m}^{-2}$ (2007 USD), based on the U.S. Department of Energy's 2010 cost goal. The Pacific Northwest National Laboratory [87] estimates the inverter cost to be $\$ 39,052$ (2013 USD) for a $270 \mathrm{~kW}$ hybrid system. The technology development company

\footnotetext{
${ }^{1}$ If the reference cost, $C_{i, 0}$, is not already expressed in $\$ \mathrm{~kW}^{-1}$ (see Table 5 ), then the right-hand side of Eqn. (24) is divided by the net power generated to yield units of $\$ \mathrm{~kW}^{-1}$.
} 
TIAX [88] estimates the air blower and fuel pre-heater costs to be on par with one another, each costing approximately $\$ 11,500$ (2002 USD) in a $250 \mathrm{~kW}$ stand-alone system. TIAX estimates the air pre-heater cost to be $\$ 144,948$ (2002 USD). R\&D Dynamics Corporation [92] estimated the fuel compressor cost to be $\$ 500$ per unit, assuming a production quantity of 50,000 units $\mathrm{yr}^{-1}$. Based on Battelle's analysis of $1 \mathrm{~kW}$ and $5 \mathrm{~kW}$ SOFC auxiliary power units [89], we estimate that assembly and testing costs to be slightly over $4 \%$ of the system's equipment cost. Boehm [90] and Turton, et al. [91] provide the generator and turbine cost parameters, respectively. The scaling exponents in Table 5 draw primarily from Braun's techno-economic analysis of residential-scale SOFC systems $[45,46]$. The system's capital cost is given by:

$$
C_{\text {system }}=\sum_{i} C_{i}
$$

where $C_{\text {system }}$ is the system's capital cost in $\$ \mathrm{~kW}^{-1}$. The uncertainty associated with the capital cost is $\pm 30 \%$. Such an estimate reflects a "study estimate," or "factored estimate" [93].

Finally, the system's initial cost (2014 USD), appearing in the LCC formula (Eqn. (16)), is given by:

$$
E_{\text {system }}=C_{\text {system }} \dot{W}_{\text {net }}
$$

The study's economic and technical parameters appear in Table 6. The equipment inflation rate is based on changes in the Chemical Engineering Plant Cost Index over the previous 10 years [94]. Similarly, the electric utility's inflation rate is estimated based on historical annual retail electricity prices in 
Table 5 Cost parameters for estimating the system components' costs. ${ }^{a}$

\begin{tabular}{|c|c|c|c|c|c|}
\hline $\begin{array}{l}\text { System } \\
\text { component }\end{array}$ & $\begin{array}{l}\text { Reference } \\
\text { capacity }\left(S_{i, 0}\right)\end{array}$ & $\begin{array}{l}\text { Reference } \\
\text { cost }\left(C_{i, 0}\right)\end{array}$ & & \multicolumn{2}{|c|}{$\begin{array}{l}\text { Scaling } \\
\text { exponent }(n)\end{array}$} \\
\hline Fuel cell stack & $A_{\text {stack }}=116.29 \mathrm{~m}^{2}$ & $\$ 68,856$ & {$[37]$} & 1.00 & \\
\hline Stack enclosure & $p_{\text {stack }}=1.21 \mathrm{~atm}$ & $\$ 2,496$ & {$[37]$} & 0.33 & {$[35]$} \\
\hline Air blower & $\dot{W}_{\text {blower }}=5.7 \mathrm{~kW}$ & $\$ 6,643$ & {$[88]$} & 0.807 & {$[45,46]$} \\
\hline Air filter & $\dot{W}_{\text {blower }}=5.7 \mathrm{~kW}$ & $\$ 306$ & {$[88]$} & 0.807 & {$[45,46]$} \\
\hline Fuel compressor & $\dot{W}_{\text {comp,fuel }}=1.1 \mathrm{~kW}$ & $\$ 500$ & {$[92]$} & 0.67 & {$[45]$} \\
\hline Desulfurizer & $\dot{m}_{\text {desulfizer }}=2.47 \mathrm{~g} \mathrm{~s}^{-1}$ & $\$ 1,176$ & {$[87]$} & 0.67 & {$[45,46]$} \\
\hline Ejector & $\dot{m}_{\text {ejector }}=36.27 \mathrm{~g} \mathrm{~s}^{-1}$ & $\$ 116$ & {$[81]$} & 0.67 & {$[45,46]$} \\
\hline Air pre-heater & $U A_{\mathrm{air}}=343.74 \mathrm{~W} \mathrm{~K}^{-1}$ & $\$ 22,444$ & {$[88]$} & 0.67 & {$[45]$} \\
\hline Fuel pre-heater & $U A_{\text {fuel }}=18.08 \mathrm{~W} \mathrm{~K}^{-1}$ & $\$ 13,601$ & {$[88]$} & 0.67 & {$[45]$} \\
\hline Heat recovery & $U A_{\text {cogen }}=387.69 \mathrm{~W} \mathrm{~K}^{-1}$ & $\$ 26,951$ & {$[10]$} & 0.67 & {$[45]$} \\
\hline Inverter & $\dot{W}_{\text {net }}=84.2 \mathrm{~kW}$ & $\$ 190 \mathrm{~kW}^{-1}$ & {$[87]$} & -0.22 & {$[45,46]$} \\
\hline Auxiliary combustor & $\dot{m}_{\mathrm{comb}}=175.19 \mathrm{~g} \mathrm{~s}^{-1}$ & $\$ 4,211$ & {$[89]$} & 0.82 & {$[46]$} \\
\hline Generator & $\dot{W}_{\text {net }}=84.2 \mathrm{~kW}$ & $\$ 61 \mathrm{~kW}^{-1}$ & {$[90]$} & -0.34 & {$[90]$} \\
\hline Turbine $^{\mathrm{c}}$ & - & - & - & - & - \\
\hline Additional $\mathrm{BOP}^{\mathrm{b}}$ & $\dot{W}_{\text {net }}=84.2 \mathrm{~kW}$ & $\$ 58 \mathrm{~kW}^{-1}$ & {$[89]$} & -0.829 & {$[46]$} \\
\hline Assembly/testing & - & $4.31 \% \times$ equip. cost & {$[89]$} & - & - \\
\hline Installation & - & $25 \% \times$ equip. cost & {$[93]$} & - & - \\
\hline
\end{tabular}

${ }^{\text {a }}$ Costs are expressed in 2014 USD during baseline operation ( $84.2 \mathrm{~kW}$ net power).

${ }^{\mathrm{b}}$ Includes electronics and controls, instrumentation, and assembly components.

c The turbine's capital cost is calculated according to Turton, et al.'s formula [91]: $\log _{10} C_{\text {turbine }}=2.2476+1.4965 \log _{10}\left(\dot{W}_{\text {turbine }}\right)-0.1618\left[\log _{10}\left(\dot{W}_{\text {turbine }}\right)\right]^{2}$ (2001 USD), where $\dot{W}_{\text {turbine }}$ is expressed in $\mathrm{kW}$. 
Table 6 The stand-alone and hybrid systems' economic and technical parameters.

\begin{tabular}{ll}
\hline Parameter & Value \\
\hline System lifetime & 20 years \\
Equipment inflation rate & $2.78 \%$ \\
Electric utility inflation rate & $2.83 \%$ \\
Discount rate & $10 \%$ \\
Income tax rate & $35 \%$ \\
Interest rate & $8 \%$ \\
Down payment (\% capital cost) & $10 \%$ \\
Insurance and maintenance $\%$ capital cost) & $7 \%$ \\
Property tax & $0.75 \%$ \\
Salvage value & None \\
Electric capacity factor, CF & $95 \%$ \\
System availability, $A_{\text {system }}$ & $100 \%$ \\
Boiler's efficiency, $\eta_{\text {boiler }}$ & $80 \%(\mathrm{HHV})$ \\
Natural gas price & $2.94 \mathrm{c} / \mathrm{kWh}$ \\
Electricity price & $10.74 \mathrm{c} / \mathrm{kWh}$ \\
\hline
\end{tabular}

the U.S. over the previous 10 years [95]. The annual maintenance cost equals $6 \%$ of the system's capital cost based on estimates provided by Peters, et al. [93]. The maintenance cost accounts for the SOFC stack's and desulfurizer sorbent's replacement costs, assuming a fuel cell stack lifetime of five years [34] and desulfurizer sorbent lifetime of one year [46]. The property tax rate is the same as that used in the Pacific Northwest National Laboratory's cost analysis of a $270 \mathrm{~kW}$ hybrid system [87]. The auxiliary boiler's efficiency is based on ASHRAE's estimates of conventional steam generation technologies [96]. The average retail electricity price for commercial customers is $10.74 \mathrm{c} \mathrm{kWh}^{-1}$ (2014 USD) [95], and the fuel cost is the average commercial natural gas price in 2014 of $2.94 \mathrm{c} \mathrm{kWh}^{-1}$ [97]. 


\subsection{Results}

\subsubsection{Baseline performance}

Figure 5a presents the systems' life cycle costs during electric-only (EO) and cogeneration (CHP) operation. EO operation assumes that the system generates power only, meaning $\dot{Q}_{\text {recovery }}=0 \mathrm{~kW}$ in Eqn. (18), and the auxiliary boiler meets the thermal energy demand entirely. The present study normalizes all life cycle costs by the stand-alone system's life cycle cost during EO operation. As shown in Fig. 5a, the hybrid system costs less than the stand-alone system during EO and CHP operation. The fuel cell stack's cost drives the stand-alone system's capital cost upward. The stand-alone system's fuel cell stack costs $\$ 818 / \mathrm{kW}$, constituting $30 \%$ of the system's capital cost. The hybrid system's fuel cell stack costs $\$ 282 / \mathrm{kW}$, constituting $12 \%$ of the system's capital cost. As shown in Fig. 5b, the amount of money saved by the hybrid and stand-alone systems depends on the systems' operation. During EO operation, both systems lose money relative to the conventional system, but the hybrid system comes closer to breaking even. During CHP operation, the hybrid system saves nearly three times more money than the stand-alone system. 


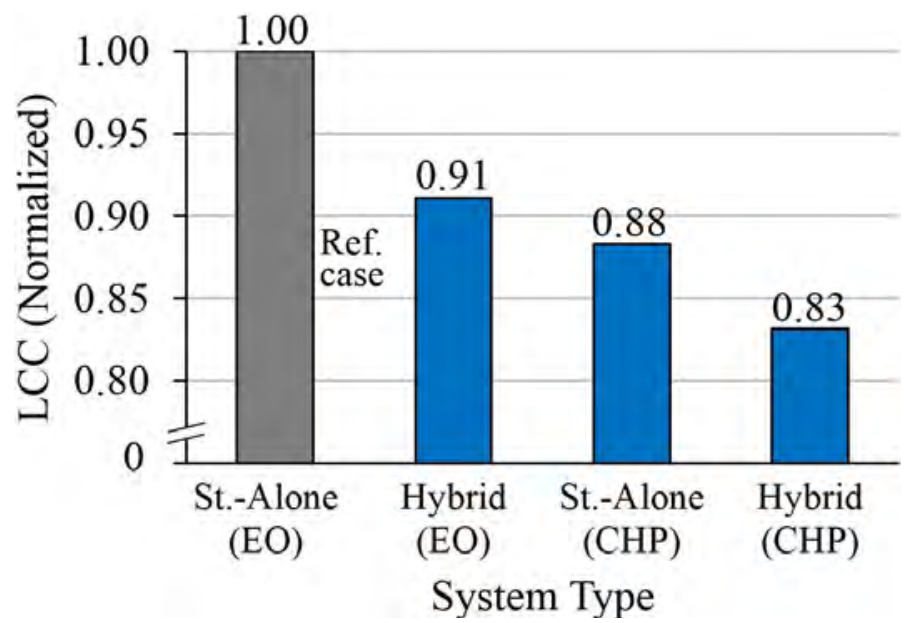

(a)

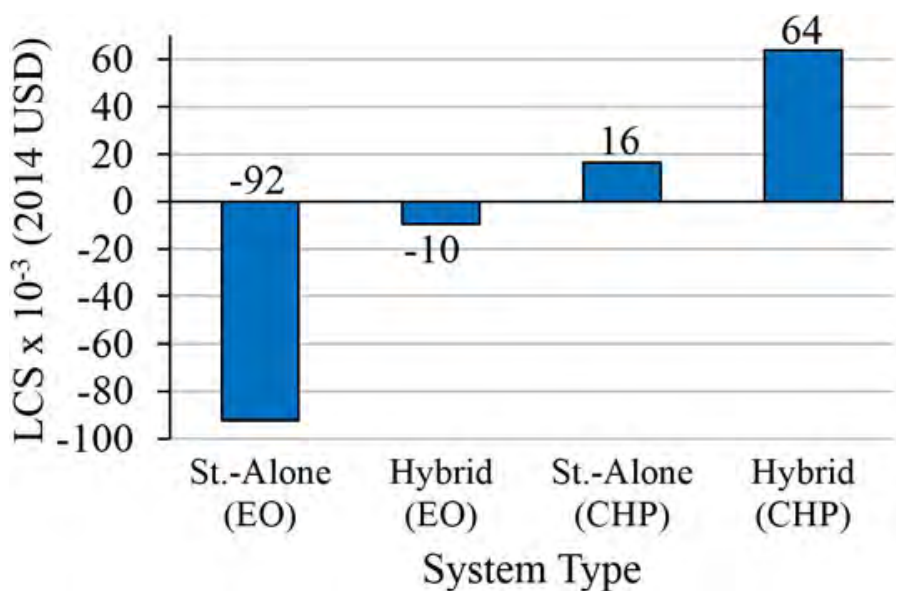

(b)

Figure 5 The stand-alone and hybrid systems' economic results during baseline operation: (a) Life cycle cost, normalized by the reference case, during baseline operation, (b) Life cycle savings. 


\subsubsection{Multivariable parametric analysis}

In order to identify local minima in the systems' life cycle costs, the present study varies the fuel cell's operating parameters. The stand-alone system's operating voltage $\left(V_{\text {cell }}\right)$ varies between $0.6 \mathrm{~V}$ and $0.8 \mathrm{~V}$, the fuel utilization $\left(U_{\mathrm{f}, \mathrm{sys}}\right)$ varies between 0.7 and 0.9 , and the average PEN temperature $\left(T_{\mathrm{PEN} \text {,average }}\right)$ varies between $700^{\circ} \mathrm{C}$ and $850^{\circ} \mathrm{C}$. Braun [46] considered these ranges when minimizing a stand-alone system's cost. Varying the system's operating parameters over these ranges, especially the PEN temperature, significantly influences the component costs (Eqn. (24)). Increasing the temperature above $850^{\circ} \mathrm{C}$ requires ceramic interconnect [46], the cost of which is not included in the present study. Figure 6 presents the stand-alone system's life cycle cost vs. PEN temperature and operating voltage during CHP operation at $85 \%$ fuel utilization (Fig. 6a) and $90 \%$ fuel utilization (Fig. 6b). In both subfigures, the life cycle cost exhibits parabolic curvature with respect to voltage. Such behavior reflects the trade-off between between fuel and capital costs. That is, increasing the fuel cell's operating voltage increases the fuel cell's electric efficiency, thereby reducing the system's fuel costs. Increasing the fuel cell's operating voltage also reduces the fuel cell's power density, however, thereby increasing the fuel cell stack's capital cost. In both subfigures, increasing the PEN temperature reduces the system's life cycle cost. Increasing the fuel cell's temperature increases the fuel cell's power density, thereby reducing the system's capital cost. Lastly, increasing the fuel utilization from $85 \%$ (Fig. 6a) to $90 \%$ (Fig. 6b) elevates the life cycle cost across all values of the temperature and voltage considered. The stand-alone system yields a minimum normalized life cycle cost of 0.74 at $V_{\text {cell }}=0.725 \mathrm{~V}, U_{\mathrm{f}, \mathrm{sys}}=0.775$, and $T_{\mathrm{PEN}, \text { average }}=850^{\circ} \mathrm{C}$. 
Similar to the stand-alone system, the hybrid system's life cycle cost depends on numerous operating parameters. The present study varies the hybrid system's operating voltage between $0.6 \mathrm{~V}$ and $0.8 \mathrm{~V}$, fuel utilization between 0.7 and 0.9 , and average PEN temperature between $650^{\circ} \mathrm{C}$ and $850^{\circ} \mathrm{C}$. The pressure ratio and turbine inlet temperature remain constant during these analyses. Figure 6 presents the hybrid system's life cycle cost vs. PEN temperature and operating voltage during CHP operation at $85 \%$ fuel utilization (Fig. 6c) and 90\% fuel utilization (Fig. 6d). The surface in Fig. 6c spans $V_{\text {cell }}=0.625 \mathrm{~V}$ and $0.725 \mathrm{~V}$. Outside this range, the model fails to yield a solution at certain temperatures. Similar to the stand-alone system, the hybrid system's life cycle cost exhibits parabolic curvature with respect to voltage, particularly at lower temperatures and $90 \%$ fuel utilization (Fig. 6d), again reflecting the trade-off between the system's fuel and capital costs. The hybrid system's life cycle cost also exhibits parabolic curvature with respect to temperature. As the temperature increases, the additional methane and stack area decrease, whereas the heat recovery decreases and air pre-heater $U A$ product increases. After performing the parametric analysis, the hybrid system exhibits a minimum normalized life cycle cost of 0.79 at the following operating parameters: $V_{\text {cell }}=0.725 \mathrm{~V}, U_{\mathrm{f}, \mathrm{sys}}=0.80$, and $T_{\mathrm{PEN}, \text { average }}=725^{\circ} \mathrm{C}$. 


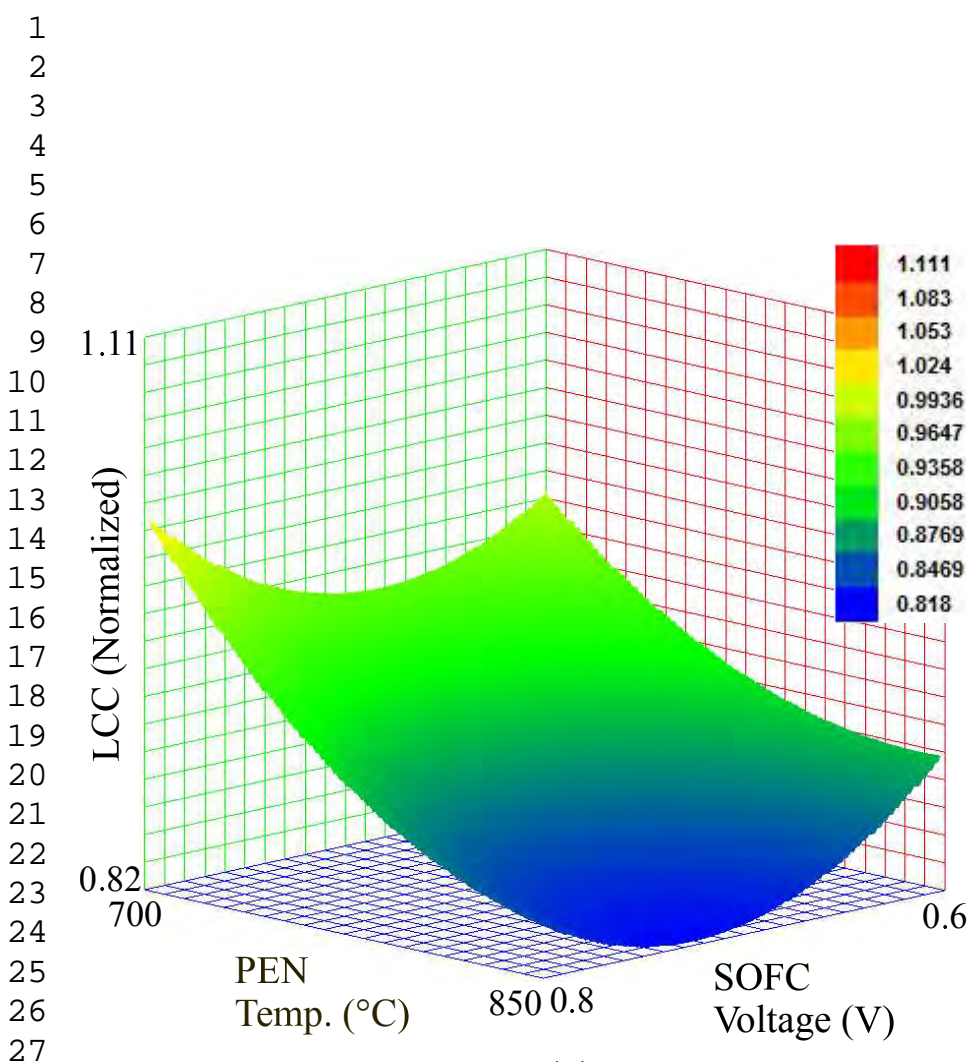

(a)

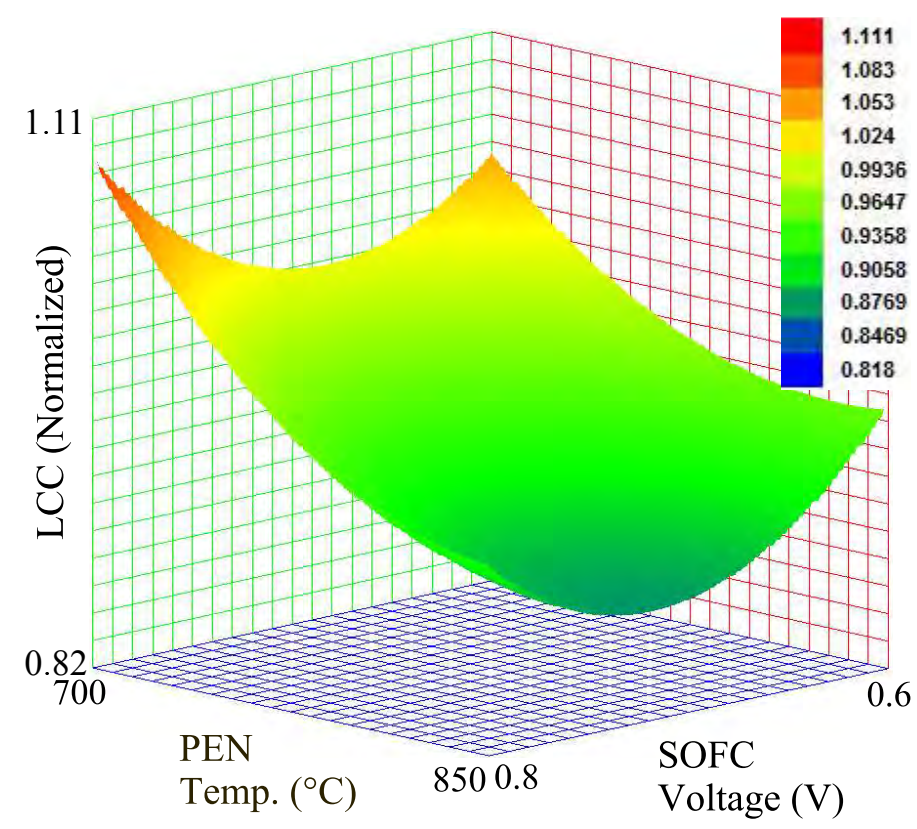

28

29

30

31

32

33

34

35

36 
Figure 7 Varying the turbine inlet temperature and pressure ratio at $V_{\text {cell }}=0.725 \mathrm{~V}$, $U_{\mathrm{f}, \mathrm{sys}}=0.80$, and $T_{\mathrm{PEN}, \text { average }}=725^{\circ} \mathrm{C}$.

In addition to varying the hybrid system's fuel cell operating parameters, the present study separately varied the hybrid system's pressure ratio (PR) between three and four, and the turbine inlet temperature (TIT) between $1,125^{\circ} \mathrm{C}$ and $1,250^{\circ} \mathrm{C}$. Martinez, et al. recommended maintaining the hybrid system's turbine inlet temperature below $1,250^{\circ} \mathrm{C}[6]$. Figure 7 presents the hybrid system's life cycle cost vs. the turbine inlet temperature and pressure ratio. Increasing the turbine inlet temperature steadily reduces the system's life cycle cost. Higher turbine inlet temperatures generally correspond to higher microturbine efficiencies, thus reducing the system's operating cost. Increasing the system's pressure ratio from three to four reduces the system's life cycle cost. The minimum life cycle cost of 0.78 occurs at $\mathrm{PR}=4$ and $\mathrm{TIT}=1,250^{\circ} \mathrm{C}$, and the optimal fuel cell operating parameters stated in the previous paragraph. Following the turbomachinery's optimization, we again varied the fuel cell's operating parameters, assuming $\mathrm{PR}=4$ and $\mathrm{TIT}=1,250^{\circ} \mathrm{C}$. The minimum life cycle cost of 0.76 occurs at $V_{\text {cell }}=0.75 \mathrm{~V}$, $U_{\mathrm{f}, \mathrm{sys}}=0.80$, and $T_{\mathrm{PEN}, \text { average }}=775^{\circ} \mathrm{C}$. 


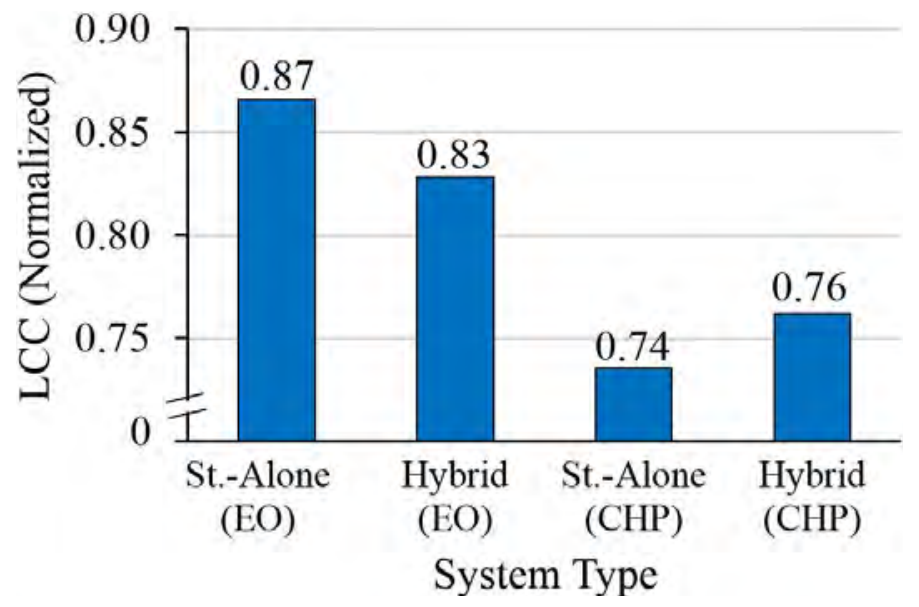

(a)

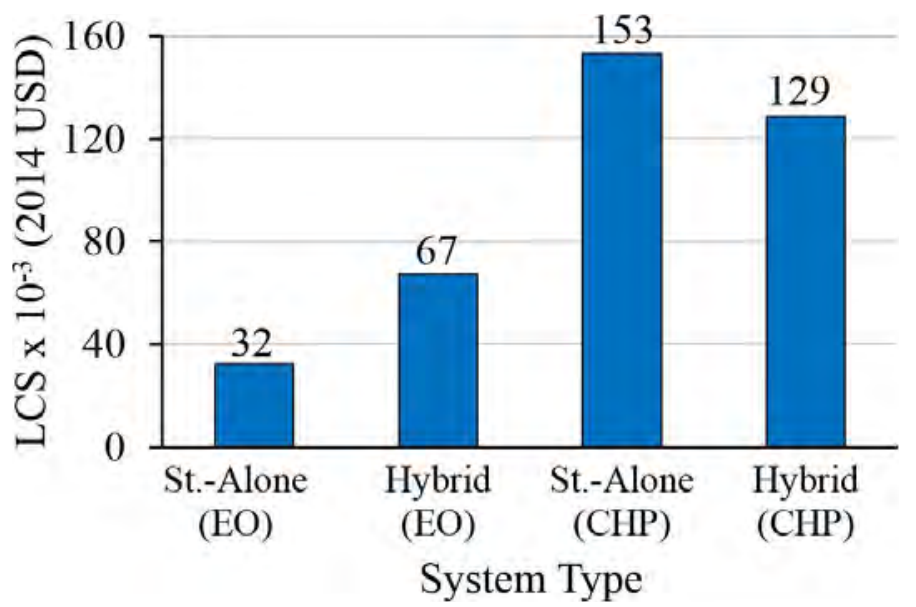

(b)

Figure 8 The stand-alone and hybrid systems' economic results. The systems have been optimized during CHP operation: (a) Normalized life cycle cost, (b) Life cycle savings.

\subsubsection{Optimized performance}

Figure 8 presents the systems' economic results after optimizing the systems. Figure 8a compares the systems' life cycle costs. During EO and CHP operation, the system costs differ slightly. Figure 8b presents the systems' life 
cycle savings. Unlike the baseline results, both systems save money relative to the conventional system during EO operation. The hybrid system saves over twice as much money as the stand-alone system during EO operation. During CHP operation, the hybrid system saves 16\% less money than the stand-alone system. Thus, the stand-alone system outperforms the hybrid system after optimization and during cogeneration.

\section{Conclusions}

The present study compared a hybrid system's exergetic and economic performance with that of a stand-alone system. The hybrid system's exergetic efficiency exceeded that of the stand-alone system by six percentage points during baseline operation. Increasing the fuel cell's operating voltage from slightly over $0.5 \mathrm{~V}$ to $0.8 \mathrm{~V}$ increased the hybrid system's exergetic efficiency by 12 percentage points, and the stand-alone system's exergetic efficiency by 22 percentage points. Varying other operating parameters, including the fuel utilization and pressure ratio, also influenced the systems' exergetic performance, though to a lesser extent. The hybrid system cost less than the stand-alone system during baseline operation. The stand-alone system outperformed the hybrid system after optimizing the system and when cogenerating thermal energy. Under these conditions, the stand-alone system saved approximately $\$ 153,000$ relative to a conventional system, whereas the hybrid system saved approximately $\$ 129,000$.

The present study's findings support hybrid systems' continued development. Hybrid systems perform particularly well during electric-only operation, which may include remote power applications. Stand-alone systems 
outperform hybrid systems following optimization and during cogeneration operation. Stand-alone systems may thus be better suited for cogeneration applications, including manufacturing processes, commercial buildings, and similar applications that demand coincident power and thermal energy. It is recommended that future work simulate hybrid and stand-alone systems under a range of thermal-to-electric ratios to reflect different building types and operation. We also recommend that future work optimize the systems during electric-only operation. The systems' part-load performance, dynamic behavior, and environmental impacts serve as additional topics for future work.

\section{Acknowledgment}

This material is based upon work supported by the National Science Foundation under grant no. EFRI-1038139.

\section{References}

[1] S. H. Chan, H. K. Ho, Y. Tian, Modelling for Part-Load Operation of Solid Oxide Fuel Cell-Gas Turbine Hybrid Power Plant, Journal of Power Sources 114 (2) (2003) 213-227.

[2] S. H. Chan, H. K. Ho, Y. Tian, Modelling of Simple Hybrid Solid Oxide Fuel Cell and Gas Turbine Power Plant, Journal of Power Sources 109 (1) (2002) 111-120.

[3] S. H. Chan, H. K. Ho, Y. Tian, Multi-Level Modeling of SOFC-Gas Turbine Hybrid System, International Journal of Hydrogen Energy 28 (8) (2003) 889-900. 
[4] S. Campanari, Full Load and Part-Load Performance Prediction for Integrated SOFC and Microturbine Systems, Journal of Engineering for Gas Turbines and Power 122 (2) (2000) 239-246.

[5] C. Stiller, B. Thorud, O. Bolland, R. Kandepu, L. Imsland, Control Strategy for a Solid Oxide Fuel Cell and Gas Turbine Hybrid System, Journal of Power Sources 158 (1) (2006) 303-315.

[6] A. S. Martinez, J. Brouwer, G. S. Samuelsen, Feasibility Study for SOFC-GT Hybrid Locomotive Power: Part I. Development of a Dynamic 3.5 MW SOFC-GT FORTRAN Model, Journal of Power Sources 213 (2012) 203-217.

[7] Capstone Turbine Corporation, Media Assets, Online at 〈http:// Www. capstoneturbine.com/news/media-assets) (see document titled "Product Catalog"). Accessed on July 14, 2016 (Copyright 2016).

[8] FlexEnergy, Brochures and Spec Sheets, Online at $\langle$ http://www . flexenergy.com/flexenergy_literature.html) (see documents titled, "Flex Turbine GT250S," and, "Flex Turbine GT333S"). Accessed on July 14, 2016 (Copyright 2014).

[9] Bloom Energy, Products, Online at 〈http://www.bloomenergy.com/ fuel-cell/energy-server/> (see links titled, 'ES5 Data Sheet," "ES5710 Data Sheet," and "ES-5700 Data Sheet"). Accessed on July 14, 2016 (Copyright 2016).

[10] K. Darrow, R. Tidball, J. Wang, and A. Hampson, Catalog of 
CHP Technologies, Accessed online at /http://www.epa.gov/chp/ technologies.htmly, U.S. Environmental Protection Agency (2015).

[11] S. E. Veyo, L. A. Shockling, J. T. Dederer, J. E. Gillett, W. L. Lundberg, Tubular Solid Oxide Fuel Cell/Gas Turbine Hybrid Cycle Power Systems: Status, Journal of Engineering for Gas Turbines and Power 124 (4) (2002) 845-849.

[12] R. A. Roberts, J. Brouwer, Dynamic Simulation of a Pressurized 220 kW Solid Oxide Fuel-Cell-Gas-Turbine Hybrid System: Modeled Performance Compared to Measured Results, Journal of Fuel Cell Science and Technology 3 (1) (2006) 18-25.

[13] National Fuel Cell Research Center, NFCRC Research Summaries, Online at 〈http://www.nfcrc.uci.edu/3/RESEARCH/ ResearchSummaries/Default.aspx) (see documents titled, "Analyses of Hybrid Fuel Cell Gas Turbine Systems" and "Hybrid-220 kW SOFC/Micro Turbine Generator System"). Accessed on July 14, 2016 (Copyright 2016).

[14] H. Ghezel-Ayagh, J. Walzak, D. Patel, J. Daly, H. Maru, R. Sanderson, W. Livingood, State of direct fuel cell/turbine systems development, Journal of Power Sources 152 (2005) 219-225.

[15] Atrex Energy, Models, Online at 〈http://www.atrexenergy.com/ products/models $\rangle$. Accessed on July 14, 2016.

[16] Protonex, P200i, Online at /http://www.protonex.com/products/ p200i/〉. Accessed on July 14, 2016 (Copyright 2016). 
[17] M. J. Moran, H. N. Shapiro, D. D. Boettner, and M. B. Bailey, Fundamentals of Engineering Thermodynamics, 7th Edition, John Wiley \& Sons, Inc., Hoboken, NJ, 2011.

[18] S. K. Park, T. S. Kim, Comparison between pressurized design and ambient pressure design of hybrid solid oxide fuel cell-gas turbine systems, Journal of Power Sources 163 (1) (2006) 490-499.

[19] R. R., J. Brouwer, F. Jabbari, T. Junker, H. Ghezel-Ayagh, Control design of an atmospheric solid oxide fuel cell/gas turbine hybrid system: Variable versus fixed speed gas turbine operation, Journal of Power Sources 161 (1) (2006) 484-491.

[20] G. J. Williams, A. Siddle, K. Pointon, Design Optimisation of a Hybrid Solid Oxide Fuel Cell \& Gas Turbine Power Generation System, Accessed online at /http://webarchive.nationalarchives.gov.uk/+/ http://www.berr.gov.uk/files/file15212.pdf $\rangle$, ALSTOM Power Technology Centre (2001).

[21] X. Zhang, S. H. Chan, G. Li, H. K. Ho, J. Li, Z. Feng, A Review of Integration Strategies for Solid Oxide Fuel Cells, Journal of Power Sources 195 (3) (2010) 685-702.

[22] L. J. Tan, C. Yang, N. Zhou, Thermoeconomic Optimization of a Solid Oxide Fuel Cell and Proton Exchange Membrane Fuel Cell Hybrid Power System, Journal of Fuel Cell Sciene and Technology 11 (1) (2014) 011005-1-12. 
[23] F. Zink, Y. Lu, L. Schaefer, A solid oxide fuel cell system for buildings, Energy Conversion and Management 48 (3) (2007) 809-818.

[24] M. H. Nehrir, C. Wang, Modeling and Control of Fuel Cells: Distributed Generation Applications, John Wiley \& Sons, Inc., Hoboken, NJ, 2009, pages 53-55, chapter 2 .

[25] F. Calise, M. Dentice d'Accadia, A. Palombo, L. Vanoli, Simulation and Exergy Analysis of a Hybrid Solid Oxide Fuel Cell (SOFC)-Gas Turbine System, Energy 31 (15) (2006) 3278-3299.

[26] F. Calise, A. Palombo, L. Vanoli, Design and Partial Load Exergy Analysis of Hybrid SOFC-GT Power Plant, Journal of Power Sources 158 (1) (2006) 225-244.

[27] M. Gandiglio, A. Lanzini, P. Leone, M. Santarelli, R. Borchiellini, Thermoeconomic Analysis of Large Solid Oxide Fuel Cell Plants: Atmospheric vs. Pressurized Performance, Energy 55 (2013) 142-155.

[28] S. H. Chan, C. F. Low, O. L. Ding, Energy and exergy analysis of simple solid-oxide fuel-cell power systems, Journal of Power Sources 103 (2) (2002) 188-200.

[29] S. Douvartzides, F. Coutelieris, P. Tsiakaras, Exergy analysis of a solid oxide fuel cell power plant fed by either ethanol or methane, Journal of Power Sources 131 (1-2) (2004) 224-230.

[30] M. Santin, A. Traverso, L. Magistri, A. Massardo, Thermoeconomic Analysis of SOFC-GT Hybrid Systems Fed by Liquid Fuels, Energy 35 (2) (2010) 1077-1083. 
[31] E. Fontell, T. Kivisaari, N. Christiansen, J.-B. Hansen, J. Pålsson, Conceptual study of a $250 \mathrm{~kW}$ planar SOFC system for CHP application, Journal of Power Sources 131 (1-2) (2004) 49-56.

[32] D. F. Cheddie, R. Murray, Thermo-Economic Modeling of an Indirectly Coupled Solid Oxide Fuel Cell/Gas Turbine Hybrid Power Plant, Journal of Power Sources 195 (24) (2010) 8134-8140.

[33] W. L. Becker, R. J. Braun, M. Penev, M. Melaina, Design and Technoeconomic Performance Analysis of a 1 MW Solid Oxide Fuel Cell Polygeneration System for Combined Production of Heat, Hydrogen, and Power, Journal of Power Sources 200 (2012) 34-44.

[34] N. S. Siefert, S. Litster, Exergy and Economic Analyses of Advanced IGCC-CCS and IGFC-CCS Power Plants, Applied Energy 107 (2013) $315-328$.

[35] N. S. Siefert, B. Y. Chang, S. Litster, Exergy and Economic Analysis of a CaO-Looping Gasifier for IGFC-CCS and IGC-CCS, Applied Energy 128 (2014) 230-245.

[36] A. K. S. Iyengar, R. A. Newby, D. L. Keairns, Techno-Economic Analysis of Integrated Gasification Fuel Cell Systems Created by Energy Sector Planning and Analysis for SEAP \& OPPB, Accessed online at /http://netl.doe.gov/File\%20Library/Research/Energy\% 20Analysis/Publications/341_03_05_FR_IGFC_Rev1H_20141120. pdf $\rangle$ DOE/NETL-341/112613, National Energy Technology Laboratory (2014). 
[37] R. Newby, D. Keairns, Analysis of Natural Gas Fuel Cell Plant Configurations-Revision 1, Accessed online at 〈http: //netl.doe.gov/File\%20Library/Research/Energy\%20Analysis/ Publications/341_02_20_FR_rev2A_20140221_NGFC_Cost_Study . pdf $\rangle$ DOE/NETL-2013/1593, National Energy Technology Laboratory (2013).

[38] N. S. Siefert, S. Litster, Exergy \& Economic Analysis of Biogas Fueled Solid Oxide Fuel Cell Systems, Journal of Power Sources 272 (2014) 386-397.

[39] A. A. Trendewicz, R. J. Braun, Techno-Economic Analysis of Solid Oxide Fuel Cell-Based Combined Heat and Power Systems for Biogas Utilization at Wastewater Treatment Facilities, Journal of Power Sources 233 (2013) 380-393.

[40] A. Franzoni, L. Magistri, A. Traverso, A. F. Massardo, Thermoeconomic Analysis of Pressurized Hybrid SOFC Systems with $\mathrm{CO}_{2}$ Separation, Energy 33 (2) (2008) 311-320.

[41] W. L. Lundberg, R. A. Holmes, J. E. King, G. A. Israelson, P. R. Zafred, R. E. Kothmann, R. R. Moritz, S. E. Veyo, Pressurized Solid Oxide Fuel Cell/Gas Turbine Power System, Accessed online at /http://www . osti.gov/scitech/servlets/purl/772401/〉, Siemens Westinghouse Power Corporation and Rolls-Royce Allison (2000).

[42] T. Kuramochi, W. Turkenburg, A. Faaij, Competitiveness of $\mathrm{CO}_{2}$ capture from an industrial solid oxide fuel cell combined heat and power 
system in the early stage of market introduction, Fuel 90 (3) (2011) 958-973.

[43] T.-P. Chen, J. D. Wright, K. Krist, SOFC System Analysis (available at http://www.netl.doe.gov/publications/proceedings/97/97fc/fc4-3.pdf).

[44] F. Calise, M. Dentice d Accadia, L. Vanoli, M. R. von Spakovsky, Full load synthesis/design optimization of a hybrid SOFC-GT power plant, Energy 32 (4) (2007) 446-458. doi:10.1016/j.energy.2006.06.016.

URL http://dx.doi.org/10.1016/j.energy . 2006.06.016

[45] R. J. Braun, Optimal Design and Operation of Solid Oxide Fuel Cell Systems for Small-Scale Stationary Applications, PhD Thesis, University of Wisconsin-Madison (2002).

[46] R. J. Braun, Techno-Economic Optimal Design of Solid Oxide Fuel Cell Systems for Micro-Combined Heat and Power Applications in the U.S., Journal of Fuel Cell Science and Technology 7 (3) (2010) 031018.

[47] R. J. Braun, S. A. Klein, D. T. Reindl, Evaluation of system configurations for solid oxide fuel cell-based micro-combined heat and power generators in residential applications, Journal of Power Sources 158 (2) (2006) 1290-1305.

[48] A. Hawkes, M. Leach, Impacts of Temporal Precision in Optimisation Modelling of Micro-Combined Heat and Power, Energy 30 (10) (2005) 1759-1779.

[49] A. D. Hawkes, M. A. Leach, Cost-Effective Operating Strategy for Residential Micro-Combined Heat and Power, Energy 32 (5) (2007) 711-723. 
[50] A. Hawkes, M. Leach, Solid Oxide Fuel Cell Systems for Residential Micro-Combined Heat and Power in the UK: Key Economic Drivers, Journal of Power Sources 149 (2005) 72-83.

[51] A. D. Hawkes, D. J. L. Brett, N. P. Brandon, Fuel Cell Micro-CHP Techno-Economics: Part 1-Model Concept and Formulation, International Journal of Hydrogen Energy 34 (23) (2009) 9545-9557.

[52] A. D. Hawkes, D. J. L. Brett, N. P. Brandon, Fuel Cell Micro-CHP Techno-Economics: Part 2-Model Application to Consider the Economic and Environmental Impact of Stack Degradation, International Journal of Hydrogen Energy 34 (23) (2009) 9558-9569.

[53] A. D. Hawkes, P. Aguiar, C. A. Hernandez-Aramburo, M. A. Leach, N. P. Brandon, T. C. Green, C. S. Adjiman, Techno-Economic Modelling of a Solid Oxide Fuel Cell Stack for Micro Combined Heat and Power, Journal of Power Sources 156 (2) (2006) 321-333.

[54] A. D. Hawkes, P. Aguiar, B. Croxford, M. A. Leach, C. S. Adjiman, N. P. Brandon, Solid Oxide Fuel Cell Micro Combined Heat and Power System Operating Strategy: Options for Provision of Residential Space and Water Heating, Journal of Power Sources 164 (1) (2007) 260-271.

[55] M. M. Whiston, M. M. Bilec, L. A. Schaefer, SOFC Stack Model for Integration into a Hybrid System: Stack Response to Control Variables, Journal of Fuel Cell Science and Technology 12 (3) (2015) 031006-1-11.

[56] M. M. Whiston, W. O. Collinge, M. M. Bilec, L. A. Schaefer, Dynamic Response of a Solid Oxide Fuel Cell Stack to Changes in a University 
Building's Load, in: ASME 2014 International Mechanical Engineering Congress and Exposition, Vol. 6A, 2014, pp. V06AT07A062-1-14.

[57] M. M. Whiston, Development and Analysis of a Hybrid Solid Oxide Fuel Cell Microturbine System, PhD Thesis, University of Pittsburgh (2015).

[58] M. M. Whiston, M. M. Bilec, L. A. Schaefer, Influence of the charge double layer on solid oxide fuel cell stack behavior, Journal of Power Sources 293 (2015) 767-777.

[59] Atrex Energy, About Atrex Tubular SOFC, Online at 〈http: //www . atrexenergy. com/technology/about-atrex-tubular-sofc $\rangle$. Accessed on July 14, 2016.

[60] FuelCell Energy, Inc., Products, Online at /http://www. fuelcellenergy.com/products-services/products/ $\rangle$ (see document titled "white paper"). Accessed on November 16, 2015 (Copyright 2013).

[61] A. S. Martinez, J. Brouwer, G. S. Samuelsen, Feasibility Study for SOFC-GT Hybrid Locomotive Power Part II. System Packaging and Operating Route Simulation, Journal of Power Sources 213 (2012) 358374.

[62] W. J. Yang, S. K. Park, T. S. Kim, J. H. Kim, J. L. Sohn, S. T. Ro, Design performance analysis of pressurized solid oxide fuel cell/gas turbine hybrid systems considering temperature constraints, Journal of Power Sources 160 (1) (2006) 462-473. 
[63] P. Costamagna, L. Magistri, A. F. Massardo, Design and part-load performance of a hybrid system based on a solid oxide fuel cell reactor and a micro gas turbine, Journal of Power Sources 96 (2) (2001) 352-368.

[64] F. Leucht, W. G. Bessler, J. Kallo, K. A. Friedrich, H. MüllerSteinhagen, Fuel Cell System Modeling for Solid Oxide Fuel Cell/Gas Turbine Hybrid Power Plants, Part I: Modeling and Simulation Framework, Journal of Power Sources 196 (3) (2011) 1205-1215.

[65] F. Mueller, J. Brouwer, F. Jabbari, S. Samuelsen, Dynamic simulation of an integrated solid oxide fuel cell system including current-based fuel flow control, Journal of Fuel Cell Science and Technology 3 (2) (2006) 144.

[66] A. Arsalis, Thermoeconomic modeling and parametric study of hybrid SOFC - gas turbine - steam turbine power plants ranging from 1.5 to 10 MWe, Journal of Power Sources 181 (2) (2008) 313-326.

[67] S. A. Klein, Engineering Equation Solver (EES). V9.927 (Copyright 2015).

[68] P. Aguiar, C. S. Adjiman, N. P. Brandon, Anode-Supported Intermediate-Temperature Direct Internal Reforming Solid Oxide Fuel Cell: II. Model-Based Dynamic Performance and Control, Journal of Power Sources 147 (1-2) (2005) 136-147.

[69] P. Aguiar, C. S. Adjiman, N. P. Brandon, Anode-Supported Intermediate Temperature Direct Internal Reforming Solid Oxide Fuel Cell. 
I: Model-Based Steady-State Performance, Journal of Power Sources 138 (1-2) (2004) 120-136.

[70] C. Stiller, B. Thorud, S. Seljebø, O. Mathisen, H. Karoliussen, O. Bolland, Finite-volume modeling and hybrid-cycle performance of planar and tubular solid oxide fuel cells, Journal of Power Sources 141 (2) (2005) 227-240.

[71] E. Achenbach, Annex II: Modelling and Evaluation of Advanced Solid Oxide Fuel Cells: SOFC Stack Modelling, Final Report of Activity A2, International Energy Agency (1996).

[72] U. G. Bossel, Facts \& Figures, Final Report on SOFC Data, International Energy Agency and Swiss Federal Office of Energy (1992).

[73] Personal correspondence with F. J. Rohr. ABB Research Center Heidelberg/Germany.

[74] E. Achenbach, E. Riensche, Methane/steam reforming kinetics for solid oxide fuel cells, Journal of Power Sources 52 (2) (1994) 283-288.

[75] J. Thijssen, LLC, The Impact of Scale-Up and Production Volume on SOFC Manufacturing Cost, Accessed online at /https://www.netl.doe.gov/File\%20Library/research/coal/ energy\%20systems/fuel\%20cells/JT-Manufacturing-StudyReport-070522.pdf $\rangle$, National Energy Technology Laboratory (2007). 
[76] F. P. Incropera, D. P. DeWitt, T. L. Bergman, A. S. Lavine, Fundamentals of Heat and Mass Transfer, 6th Edition, John Wiley \& Sons, Inc., Hoboken, NJ, 2007.

[77] R. B. Bird, W. E. Stewart, E. N. Lightfoot, Transport Phenomena, revised 2nd Edition, John Wiley \& Sons, Inc., New York, NY, 2007, pp. 460-461, chap. 15.

[78] V. Liso, A. C. Olesen, M. P. Nielsen, S. K. Kær, Performance comparison between partial oxidation and methane steam reforming processes for solid oxide fuel cell (SOFC) micro combined heat and power (CHP) system, Energy 36 (7) (2011) 4216-4226.

[79] F. Marsano, L. Magistri, A. F. Massardo, Ejector performance influence on a solid oxide fuel cell anodic recirulation system, Journal of Power Sources 129 (2) (2004) 216-228.

[80] Y. Zhu, W. Cai, C. Wen, Y. Li, Fuel ejector deisgn and simulation model for anodic recirculation sofc system, Journal of Power Sources 173 (1) (2007) 437-449.

[81] A. D. Little, Inc., Conceptual Design of POX/SOFC 5kW Net System, Accessed online at /https://www.netl.doe.gov/File\% 20Library/research/coal/energy\%20systems/fuel\%20cells/ conceptualdesignofpoxsofc5kwnetsystem.pdf $\rangle$, National Energy Technology Laboratory (2001).

[82] E. Riensche, U. Stimming, G. Unverzagt, Optimization of a $200 \mathrm{~kW}$ 
SOFC Cogeneration Power Plant Part I: Variation of Process Parameters, Journal of Power Sources 73 (2) (1998) 251-256.

[83] W. L. Lundberg, Solid Oxide Fuel Cell Cogeneration System Conceptural Design, Tech. Rep. GRI-89/0162, Gas Research Institute (1989).

[84] S. Klein, G. Nellis, Thermodynamics, Cambridge University Press, New York, NY, 2011.

[85] J. A. Duffie, W. A. Beckman, Solar Engineering of Thermal Processes, 4th Edition, John Wiley \& Sons, Inc., Hoboken, NJ, 2013, pages 447476, chapter 11.

[86] W. G. Sullivan, E. M. Wicks, and C. P. Koelling, Engineering Economy, 15th Edition, Pearson Higher Education, Inc., Upper Saddle River, NJ, 2012.

[87] M. R. Weimar, L. A. Chick, D. W. Gotthold, and G. A. Whyatt, Cost Study for Manufacturing of Solid Oxide Fuel Cell Power Systems, Accessed online at /http://www .pnnl.gov/main/publications/ external/technical_reports/PNNL-22732.pdf $\rangle$, Pacific Northwest National Laboratory (2013).

[88] TIAX LLC, Scale-Up Study of 5-kW SECA modules to a 250$\mathrm{kW}$ System, Accessed online at /http://www.netl.doe.gov/File\% 20Library/research/coal/energy\%20systems/fuel\%20cells/ scaleupstudyof 5kwsecamodulestoa250kw.pdf $\rangle$, National Energy Technology Laboratory (2002). 
[89] Battelle, Manufacturing Cost Analysis of $1 \mathrm{~kW}$ and $5 \mathrm{~kW}$ Solid Oxide Fuel Cell (SOFC) for Auxiliary Power Applications, Accessed online at /http://energy.gov/sites/prod/files/2014/06/f16/fcto_ battelle_cost_analysis_apu_feb2014.pdf), U.S. Department of Energy (2014).

[90] R. F. Boehm, Design Analysis of Thermal Systems, John Wiley \& Sons, Inc., New York, NY, 1987.

[91] R. Turton, R. C. Bailie, W. B. Whiting, J. A. Shaeiwitz, D. Bhattacharyya, Analysis, Synthesis, and Design of Chemical Processes, 4th Edition, Pearson Education, Inc., Upper Saddle River, NJ, 2012.

[92] Personal communication with John Vandermeer, Business Manager at R\&D Dynamics Corporation, July 21, 2016, and Dennis Burr, Business Development Director at R\&D Dynamics Corporation, July 22, 2016.

[93] M. S. Peters, K. D. Timmerhaus, R. E. West, Plant Design and Economics for Chemical Engineers, 5th Edition, The McGraw-Hill Companies, Inc., Boston, MA, 2003.

[94] Access Intelligence, LLC, Chemical Engineering Plant Cost Index, Accessed online at $\langle$ http://www.chemengonline.com/pci $\rangle$. Accessed on November 16, 2015 (Copyright 2015).

[95] U.S. Energy Information Administration, Electricity, Accessed online at $\langle$ http://www.eia.gov/electricity/data.cfm〉 (see "Sales (consumption), revenue, prices \& customers"). Accessed on July 19, 2016. 
[96] American Society of Heating, Refrigerating and Air-Conditioning (ASHRAE), Heating, Ventilating, and Air-Conditioning Systems and Equipment (SI Edition), ASHRAE, Atlanta, GA, 2012, Ch. Combined Heat and Power Systems, pp. 7.1-7.9.

[97] U.S. Energy Information Administration, Natural Gas, Accessed online at $\langle$ http://www.eia.gov/dnav/ng/ng_pri_sum_dcu_nus_m.htm $\rangle$. Accessed on July 19, 2016. 


\section{List of Tables}

Table 1 Baseline operating parameters.

Table 2 The stand-alone and hybrid systems' results during baseline operation.

Table 3 The stand-alone system's exergy accounting. All values are expressed as a percentage of the system's inlet exergy.

Table 4 The hybrid system's exergy accounting. All values are expressed as a percentage of the system's inlet exergy.

Table 5 Cost parameters for estimating the system components' costs.

Table 6 The stand-alone and hybrid systems' economic and technical parameters. 


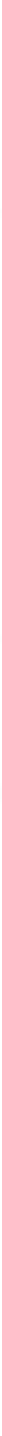

Fuel cell stack

Compressor

- _ - - - - - - $\mathbf{-}_{-1}$

Balance of plant

I $\ldots \ldots-\ldots-\ldots$ 


\section{List of Figures}

Figure 1 The stand-alone system's process flow diagram (adapted from Refs. [46, 59, 60]). Thermodynamic properties are provided during baseline operation (Table 1).

Figure 2 The hybrid system's process flow diagram (adapted from Refs. [1-6, 21, 30, 40, 41, 44, 61-66]). Thermodynamic properties are provided during baseline operation (Table 1).

Figure 3 Sensitivity of the stand-alone system's energetic and exergetic results to changes in the fuel cell's operating parameters: (a) Varying the SOFC's voltage, (b) Varying the system's fuel utilization, (c) Varying the average PEN temperature. The dashed lines indicate the minimum value of the independent variable at which a solution was found.

Figure 4 Sensitivity of the hybrid system's energetic and exergetic results to changes in the fuel cell's operating parameters: (a) Varying the SOFC's voltage, (b) Varying the system's fuel utilization, (c) Varying the average PEN temperature, (d) Varying the pressure ratio. The dashed lines indicate the minimum value of the independent variable at which a solution was found.

Figure 5 The stand-alone and hybrid systems' economic results during baseline operation: (a) Life cycle cost, normalized by the reference case, during baseline operation, (b) Life cycle savings.

Figure 6 The stand-alone and hybrid systems' optimization results, varying the SOFC's operating voltage and average PEN temperature: (a) Stand-alone, $U_{\mathrm{f}, \text { system }}=0.85$, (b) Standalone, $U_{\text {f,system }}=0.90$, (c) Hybrid, $U_{\text {f,system }}=0.85,(\mathrm{~d})$ Hybrid, $U_{\mathrm{f}, \mathrm{system}}=0.90$. 
Figure 7 Varying the turbine inlet temperature and pressure ratio, assuming $V_{\text {cell }}=0.725 \mathrm{~V}, U_{\mathrm{f}, \text { sys }}=0.80$, and $T_{\mathrm{PEN}, \text { average }}=$ $725^{\circ} \mathrm{C}$.

Figure 8 The stand-alone and hybrid systems' economic results. The systems have been optimized during CHPoperation: (a) Normalized life cycle cost, (b) Life cycle savings. 